\title{
Political ecology of health in the Land of Fires: a hotspot of environmental crimes in the south of Italy
}

\author{
Giacomo D'Alisa ${ }^{1,2}$ \\ Anna Rita Germani ${ }^{2}$ \\ Pasquale Marcello Falcone ${ }^{2,3}$ \\ Piergiuseppe Morone $e^{2,3}$ \\ ${ }^{1}$ Universitat Autònoma de Barcelona, Catalonia, Spain \\ ${ }^{2}$ University of Rome "La Sapienza", Italy \\ ${ }^{3}$ Unitelma Sapienza, Italy
}

\begin{abstract}
Environmental crimes, if they are perceived as victimless, have not received the appropriate governmental response and have been frequently ranked low on the law enforcement priority list, punished with lenient or no administrative sanctions. This has contributed to an underestimation of the immediate consequences of environmental crimes, which can go undetected for lengthy periods. On the contrary, the mismanagement and illegal trafficking of waste in the Land of Fires, an area in the Campania region in the South of Italy, has been experienced as a 'victimful' crime. Using a political ecology of health approach, and integrating qualitative and quantitative methods, we investigate how the perception of being a victim of waste-related environmental crimes has been magnified by evidence of serious disease outcomes. Health concerns have become a central issue in the resurgence of grassroots movements against waste mismanagement in Campania.
\end{abstract}

Keywords: Environmental crime, political ecology of health, waste conflict, Campania

\section{Résumé}

Les crimes contre l'environnement, s'ils sont perçus comme sans victimes, n'ont pas reçu la réponse gouvernementale appropriée et ont souvent été classés parmi les moins prioritaires dans la liste des priorités de l'application de la loi, sanctionnés par des sanctions administratives clémentes. Cela a contribué à une sous-estimation des conséquences immédiates des crimes contre l'environnement, qui peuvent passer inaperçus pendant de longues périodes. Au contraire, la mauvaise gestion et le trafic illicite de déchets dans le Land of Fires, région de la Campanie dans le sud de l'Italie, ont été vécus comme un crime avec «victimes». En utilisant une approche «écologie politique de la santé» et en intégrant des méthodes qualitatives et quantitatives, j'examine comment la perception d'être victime de crimes environnementaux liés aux déchets a été amplifiée par des preuves de graves conséquences pour la santé. Les problèmes de santé sont devenus une question centrale dans la résurgence des mouvements populaires contre la mauvaise gestion des déchets en Campanie.

Mots-clés: Crimes environnementaux, écologie politique de la santé, conflits de déchets, Campanie

\section{Resumen}

Los delitos ambientales se perciben a menudo como "crímenes sin víctimas", por lo que durante años no han recibido una respuesta apropiada por parte de los gobiernos ni tampoco han representado una prioridad para el poder judicial, siendo sancionados solo en ocasiones y con multas administrativas. Este enfoque ha contribuido a subestimar las consecuencias inmediatas de los crímenes ambientales,

\footnotetext{
${ }^{1}$ Dr. Giacomo D'Alisa, Research Fellow, Institut de Ciència i Tecnologia Ambientals (ICTA), Universitat Autònoma de Barcelona (UAB), Campus Universitari, Bellaterra $(\mathrm{Bcn})$, Spain. Email: giacomo_dalisa "at" yahoo.it. Dr. Anna Rita Germani, Department of Law Philosphy and Economic Studies, University of Rome "La Sapienza", Piazzale Aldo Moro, 5, 00185, Rome, Italy. Dr. Pasquale Marcello Falcone, Bioeconomy in Transition Research Group, IdEA, Unitelma Sapienza, Roma, Italy. Prof. Piergiuseppe Morone, Unitelma Sapienza, Roma, Italy. Acknowledgements: The authors are very grateful to the EFFACE Project for financial support. This is the fourth article in Creighton Connolly, Panagiota Kotsila, and Giacomo D'Alisa (eds.) 2016. "Tracing narratives and perceptions in the political ecology of health and disease", Special Section of the Journal of Political Ecology 24: $1-124$.
} 
que pueden pasar inadvertidas durante largos periodos de tiempo. En contraste, la mala gestión y el comercio ilegal de residuos en la Tierra de los Fuegos, un área de la región de Campania, al Sur de Italia, se han vivido como "crímenes con victimas." Mediante este estudio, usando un enfoque de ecología política de la salud e integrando métodos cualitativos y cuantitativos, tenemos el objetivo de investigar cómo la contracción de graves enfermedades influencia la percepción de ser una víctima de un crimen ambiental relacionado con la gestión de residuos. Los resultados obtenidos permiten afirmar que la preocupación sobre la salud se ha convertido en una cuestión central en la resurgencia de los movimientos de base contra la mala gestión de los residuos en Campania.

Palabras clave: Crímenes ambientales, ecología política de la salud, conflicto de residuos, Campania.

\section{Introduction}

The questionnaire ended but the conversation did not. I was telling an interviewee that although, since 2007, I (D'Alisa) have been studying and researching in Barcelona, Spain, I grew up in the same town in Italy where she lives. She stopped me and said:

I am not from here; I came and lived here because it was full of agricultural plots... So, when the doctor said to me that probably the lymphoma of my daughter could have been triggered by the polluted environment around us, I said: no this is impossible! The landscape you see from my balcony is countryside...however, since then I started looking at my environment more carefully, and I started to spot dumped waste here and there, and to see from time to time some black column of smoke rising in the distance... (ID\#13).

Just after those words, I realised how strongly the perception of what a person sees and what stays invisible to his or her gaze is determined by a personal story, experiences and events. I had not thought of my town, Casalnuovo di Napoli, as rural since I was a teenager ( $7 \mathrm{~km}$ outside Naples). At the beginning of the 1990s, massive building speculation started and a decade later, the population of the town doubled; car traffic dominated the streets, whilst farmland almost disappeared from the map. The interviewee's words were an indirect validation of the usefulness of pursuing this research: why have health issues become a central argument in the resurgence of grassroots movements against waste mismanagement in Campania? In 2012, the social coalition called Stop Biocide was formed by three main groupings of associations: Fires Coordination Committees, Campania Citizens for an Alternative Waste Management Plan, and Commons Net. They fight for:

1) a better management of urban waste;

2) the remediation of the thousands of contaminated sites in the region;

3) the halting of illegal waste trafficking, and, last but not least,

4) the implementation of a systematic health screening of the Campania population affected by illegal dumping of toxic waste.

In recent times a few oncologists, pathologists and toxicologists have used the word 'biocide' to describe the genetic weakening of the Campania population. These doctors and scientists associate this with the continuous exposure of Campania citizens to toxic contaminants produced by the illegal dumping of waste in the region (De Rosa, 2014).

'Biocide' can be considered a group effort between scholars and environmental justice movements, whose direct and indirect collaboration results in co-production of new concepts to cope with particular environmental struggles and injustice (Martinez Alier et al., 2014). The icons of the biocide movements in Campania have been the faces of the children who died from cancer, exhibited during several demonstrations in the region. Tens of thousands of postcards were sent to the President of the Italian Republic and to Pope Francis with their faces printed on them, in order to highlight the issue and to ask for direct intervention (Iengo and Armeiro, 2016). Since then, the waste mismanagement and trafficking in Campania has been experienced as a crime with real victims. Campania citizens have not only claimed to be victimized by waste-related environmental criminals, 
but have also forced the national government to criminalise illegal waste practices, which were previously considered simple misdemeanours by the Italian Environmental code (D'Alisa et al., 2015). Thus, it is important not only to investigate why health issues have become so important for the waste conflict in Campania, but also how the contraction of serious diseases (cancer, asthma, etc.) influences the perception of being a victim of waste-related environmental crimes. In doing this, we adopt a political ecology health approach in order to pave the way for addressing "the injustices embodied in the current patterns of contamination and exposure" (D'Alisa et al., 2014).

The article is organised as follows: the next section outlines the literature on environmental crime and explains why a political ecology health approach is useful to start the disentanglement of the complexity of the crimes against the environment. Section 3 focuses on the Campania case study, presenting some statistics about the region, and explaining the applied methods used. Section 4 delineates the main problems with the mismanagement of waste in the region, describes the illegal burning and burying practices in the so called 'Land of Fires', sketches the role of organised crime in the illegal trafficking of waste, and confronts the two main epidemiological narratives about the health issue in Campania, thus situating the study of victims' perception. Section 5 describes the main variables that best explain the perception of being victims of environmental crime in the "Land of Fires." The conclusion offers some policy suggestions for improving the legitimization of victims in the fight against environmental crimes.

\section{Environmental crimes and the political ecology of disease}

Environmental crimes (EC, hereafter) have consequences for ecosystems, biodiversity, governance, the economy and human health. On the other hand, as the UN's former Executive Director of the Office on Drugs and Crime underlined, illicit appropriation of natural assets, illegal logging, illegal fishing, trafficking of fauna and flora, and illegal trafficking of hazardous waste (the main environmental crimes) provide huge financial gains for some (Costa, 2008). Indeed, EC can be highly profitable business ventures, which can expand in periods of economic crisis by reducing commercial costs (Europol, 2013). This was clear for one of those interviewed:

...they want to make money.... they destroyed us, they contaminated our land, they made our sheep ill, they forced us to slaughter more than three thousand livestock, and so to close down the farm... my father died of cancer some years after with a very high level of dioxin in the blood (250 pg for each gram of blood, against the 10pg that a person with no known exposure to dioxin normally has in a gram of blood according to WHO parameters); all this just because they want to make a lot of money. (ID\#9).

According to Interpol's estimates, organised crime groups earn tens of billions of dollars every year from EC (Interpol, 2006). More recent figures ascertain EC as the most profitable criminal activity internationally (Skinnider, 2011). Critical approaches claim that EC are produced by socioeconomic systems that are oriented towards economic profit and capital accumulation, offering incentives to produce environmental harm and even "break the rules" in order to obtain increased economic benefits (White, 2008). This push for profit continues to provide incentives for criminal activity regardless of legislation and enforcement efforts, thereby hampering the implementation of effective actions to combat EC. Thus, according to some scholars, the systemic imperatives of a political economy oriented towards the generation of economic profit, counteracting regulation and enforcement efforts, are at the heart of the production of EC (Lynch and Stretsky, 2003).

Since the mid 1990s, international institutions and scholars have been denouncing the growing and serious problem that EC represents, and asking for a collective effort to address crime against the environment (ECOSOC, 1994; South, 1998). However, even if social awareness about this issue is increasing, a shared understanding of EC is still absent. Definitions abound, but lack consensus. A coordinated road map to fight these criminal activities has not been traced. For some scholars, the lack of agreement is due to the fact that EC are socially constructed phenomena (Halsey, 2004; Lynch and Stretsky, 2003; Seager, 1993; White, 2008). This is in two main ways. First, with regards to what constitutes and what does not constitute a crime, i.e. the criminalization of acts of environmental harm. This is contingent on different criminal justice systems, and their values and principles (White, 
2004). Second, EC are socially constructed in the sense that societies and, in particular, specific socioeconomic and political configurations, produce this type of crime.

In showing the plurality of existing definitions, Skinnider (2011) proposes a distinction between anthropocentric and ecocentric/biocentric approaches. There are three in the former:

(1) A legal-procedural perspective, which defines EC as a violation of criminal law;

(2) The broader socio-ecological perspective, which defines as environmental crime those offenses also included in environmental laws sanctioned as regulatory or administrative violations;

(3) The anthropocentric approach, including those sociological approaches that refer only to human interests.

On the other hand, an ecocentric approach defines as EC all those activities that heavily impact on biotic and abiotic resources, independent of the consequences for humans. More recently, a transdisciplinary research team remarked that none of the existing definitions of EC is universally accepted (EFFACE, 2014). They underlined the differences between a descriptive and normative approach. There are two descriptive approaches:

(1) The descriptive and legal, describing the activity as a crime because it is subjected to criminal sanctions;

(2) The descriptive but non-legal, which regards the activity as a crime because some people challenge it on a moral basis - even though it is not sanctioned as a criminal violation.

Normative thinkers state that all actions that have objectionable consequences for the environment should be regarded as a crime by the legal system.

The different definitions have consequences for the recognition of the victims of EC. Williams (1996) defines environmental victims as those harmed by changes in their environment due to deliberate or reckless acts or omissions. Broadly defined, anyone or anything harmed by environmental disruptions may be seen as a victim (Skinnider, 2011). However, to what extent causing environmental harm is criminalised or sanctioned may have implications for who the authorities should recognize as victims. Criminal law, generally focuses on individual victims whereas environmental legislation often describes environmental harm as an offence against the public interest. Skinnider (2011) discusses a number of ways to classify victims of environmental harm: by the nature of wrongful acts; by the extent of damages suffered; by scope of harm, or by the perpetrator and by the nature of harm. In a social harms approach, Hall (2013) provides an extended definition of environmental victims, beyond restrictive legal categories (i.e., health impacts, economic impacts, social and cultural impacts, reduced security). However, as the thesis of the slow violence of contamination has extensively demonstrated, EC do not always produce an immediate consequence and it may be difficult to quantify in monetary terms; the harm may also be diffused or go undetected for several years; and the effects of a single offence may not appear severe in the short-run even when the cumulative impact of repeated violations in the long-run can be irreparable (Nixon, 2011). These are some of the reasons why EC has often been perceived and described as "victimless" (Bricknell, 2010; Korsell, 2001; Skinnider, 2011). Of course, anthropocentric approaches see no victims if direct or indirect consequences for humans cannot be detected. Victims need to be identified by enforcement officials, and they need to self-identify (Goodey, 2005). Even if victims are aware of environmental harms, they might not consider themselves as 'victims of crime' and harms, such as terminal illness, may go unreported (Bricknell, 2010; Wiernik, 2006). It may be impossible for local communities to determine, by themselves, whether they have been exposed, or their degree of exposure. Pollution is too often invisible.

Even though environmental victims have received scarce attention, several approaches have been employed in the literature to the issue of criminal victimization. Williams (1996), White (2011), and Spencer and Fitzgerald (2013) have all underlined the need for serious development of the study 
of environmental victims and victimization. Environmental victims have been analyzed with regards to different avenues of compensation and restitution (Hall, 2013), criminal justice (Williams, 1996), and health-related harm issues (Tombs and White, 2010). The environmental justice literature has demonstrated extensively that the victims of environmental harm in the USA were typically the black and the poor (Bullard, 2005; Pellow, 2007; Pezzullo and Sandler, 2007). However, environmental victims have been notably absent from the vast majority of academic and policy debates (Hall, 2014). Even victimologists have dedicated scarce attention to the victims of EC (Skinnider, 2011). Some empirical investigations have analyzed peoples' perceptions of EC (Martín et al., 2013), and only very recently a study has taken into account the perspective of environmental victims themselves (Barclay and Bartel, 2015). The present study is a contribution to this nascent literature; it will do so through the lens of political ecology by investigating the self-perception of being a victim of EC. The recognition of the victims' voice, we maintain, is an important first step towards their empowerment. Indeed, their engagement is an effective way of tackling EC, as some scholars have already demonstrated (Cardwell, 2011).

\section{Why the political ecology lens?}

This sketch of EC literature clarifies that crimes against nature are driven by political economic forces, depend on regional environmental policies, impact on ecological systems and they produce unhealthy bodies. The complexity of EC and how to identify the victims is well expressed by one of the interviewees:

[to be a victim of an environmental crime] ...means to live in a context where an illegal activity is not a classic illegal activity... you know when I'm robbed and a bloke commits a crime. In the case of environmental crime there are a series of persons that have a share in the crime. For those that suffer this crime - all the human beings, ... the living beings that live in that habitat,... in that context...- it is very depressing and frustrating, because de facto it is very difficult to individualise the origins of the act. Because the "assault" hails from different fronts: from bad behaviour, from those people that are used to showing off, from economic interests, from bad environmental policies, from those who lack sensibility and concern [towards the others]... Thus, there is a plurality of factors that impacts on the environment and we, that suffer [the consequences], ... we are in a state of depression because it is difficult to combat the different sources of pollution". (ID\#2)

To address this socio-ecological conundrum, political ecology is a useful approach because of its interdisciplinary research design, its use of several scientific techniques and methods, for its deep concern for human/environment relations, and for its systematic study of the unequal distribution of the burdens of pollution. In particular, the political ecology of health (hereafter, PEH) is very effective for disentangling the knot of the multi-scalar and multidimensional effects of EC. Why is this? Since the 1990s, the PEH approach has been contributing to a better understanding of the relationships between political configurations, cultural and social institutions, economic interests, environmental processes, human health and diseases outcomes (Harper, 2004; Jackson and Neely, 2015; King, 2010; Mayer, 1996; Parizeau, 2015; Sultana, 2012). Moreover, PEH has proven to be a valuable approach to investigate how local understandings of diseases match or clash with the institutional representation of them, unveiling the power asymmetries that shape a particular interpretation of disease, and produce and legitimate only a certain kind of knowledge (Auyero and Swistun, 2008; King, 2010; Mangiameli 2013). Political ecologists have also underlined that the slow violence of contamination fosters health inequality (Sultana, 2012), and contributes to toxic uncertainty, because of its gradual permeability in the environment and in bodies. Furthermore, the PEH approach shows that uncertainty is not only the result of the intrinsic complexity of environmental contamination, but it is also socially produced by powerful actors that take advantage of local doubts, and reproduce errors and ignorance about the origin of toxicity (Auyero and Swistun, 2008); thus, it can also be conducive to social and political apathy (Mangiameli, 2013). Political ecologists have pushed for a response to the serious challenges that the slowness and invisibility of toxic legacy produce in everyday life (Houston and Ruming, 
2014).

In sum, PEH is a sound approach, both theoretically and pragmatically, in order to face the complexity of EC issues; the fact that up until now, to our knowledge, it has not been used it to tackle environmental crime demonstrates the urgency of the task.

\section{Land of Fires: background of the case study in Campania, Italy}

\section{Campania statistics}

Campania is among the poorest and most densely populated regions in Italy (Figure 1). Its per capita GDP in 2009 was less than $€ 13,000(\$ 13,800)$ per year - the average in Italy was more than $€ 20,000(\$ 21,250)$; in the South of Italy almost $€ 13,500(\$ 14,350)\left(\right.$ Istat $\left.^{2}\right)$.

Campania comprises five provinces: Avellino, Benevento, Caserta, Naples and Salerno. Its total population amounts to almost 6 million people, mostly concentrated in the metropolitan city of Naples (more than 3 million people), ${ }^{3}$ which represents less than $9 \%{ }^{4}$ of the total territory of the region $\left(1,170 \mathrm{~km}^{2}\right.$ and $13,590 \mathrm{~km}^{2}$, respectively $\left.{ }^{5}\right)$. The Metropolitan city of Naples has the highest population density in Italy and one of the highest in the EU. Its average population density is more than 2,500 inhabitants per $\mathrm{km}^{2}$; the municipality of Naples reaches 8,000 people per $\mathrm{km}^{2}$ and holds no more than one million inhabitants (Istat, 2011). ${ }^{6}$

In an older study commissioned by SVIMEZ (Association for the Development of the Industry in the South of Italy), a not-for-profit Italian research association that has the aim of promoting economic development in the South of Italy, the metropolitan area of Naples was interpreted as a complex urban-rural system, connecting not only the territory of the metropolitan city, but also with three other main cities (Caserta, Avellino and Salerno) and many other municipalities of those provinces (Smarrazzo, 1999). In this area, $80 \%$ of the region's population is concentrated in an intricate network of urban territories, agriculture land and commercial activity (Figure 2). In particular, the presence of several waste treatment and disposal facilities, legal and illegal, expose the area to a very high waste-related biophysical pressure (D'Alisa et al. 2012).

The area also coincides with the densest surface concentration of Potentially Contaminated Sites (PCSs) (Figure 3). The technicians of the Regional Agency for the Protection of the Environment in Campania, namely ARPAC, spotted more than 2,500 PCSs in the entire region; in the northern area of Naples alone there were 1,117, of which 822 are linked to waste disposal and 295 with different productive activities of the region (ARPAC, 2005). This highly contaminated area has been strongly affected by the illegal disposal of toxic waste since the 1980s. Later on, this area between the north of Naples and the south of Caserta became known as the Land of Fires (hereafter LoF) (Legambiente 2003; Saviano, 2006).

\section{Methods}

In order to delineate the intricacy of the Campania case, we developed two different research strategies. The aim was to situate the self-perception of being victims of environmental crime in the political economy of waste management, and also to uncover emergent health discourses about the relationship between the illegal disposal of waste and the increased morbidity and mortality in Campania.

First, by means of secondary research, we reviewed the heterogeneous literature on the correlation between cancer mortality and illegal disposal of waste, and we looked at a series of documents, such as dossiers of environmental NGOs on the Ecomafia, reports of police organizations (Europol and Interpol on environmental crime), research publications about waste management and illegal trafficking, official reports and hearings of special parliamentary commissions on waste trafficking in Italy, interviews with national anti-mafia prosecutors and articles by district prosecutors

\footnotetext{
${ }^{2}$ http://sitis.istat.it/sitis/html/

${ }_{3}^{3}$ The metropolitan city of Naples was instituted with Law 56/2014, and since the $1^{\text {st }}$ January 2015 it has replaced the Province of Naples.

${ }^{4}$ The surface area of the Metropolitan City of Naples is smaller than the Municipality of Rome $\left(1,285 \mathrm{~km}^{2}\right)$.

${ }^{5} \mathrm{http://www.statistica.regione.campania.it//}$

${ }^{6} \mathrm{http}: / /$ dati-censimentopopolazione.istat.it/?lang=it
} 
that investigate waste trafficking, and some of the extensive grey literature on LoF (newspapers, documents and flyers produced by grassroots movements, etc.). Second, the research on victims resulted from a collection and analysis of primary data.

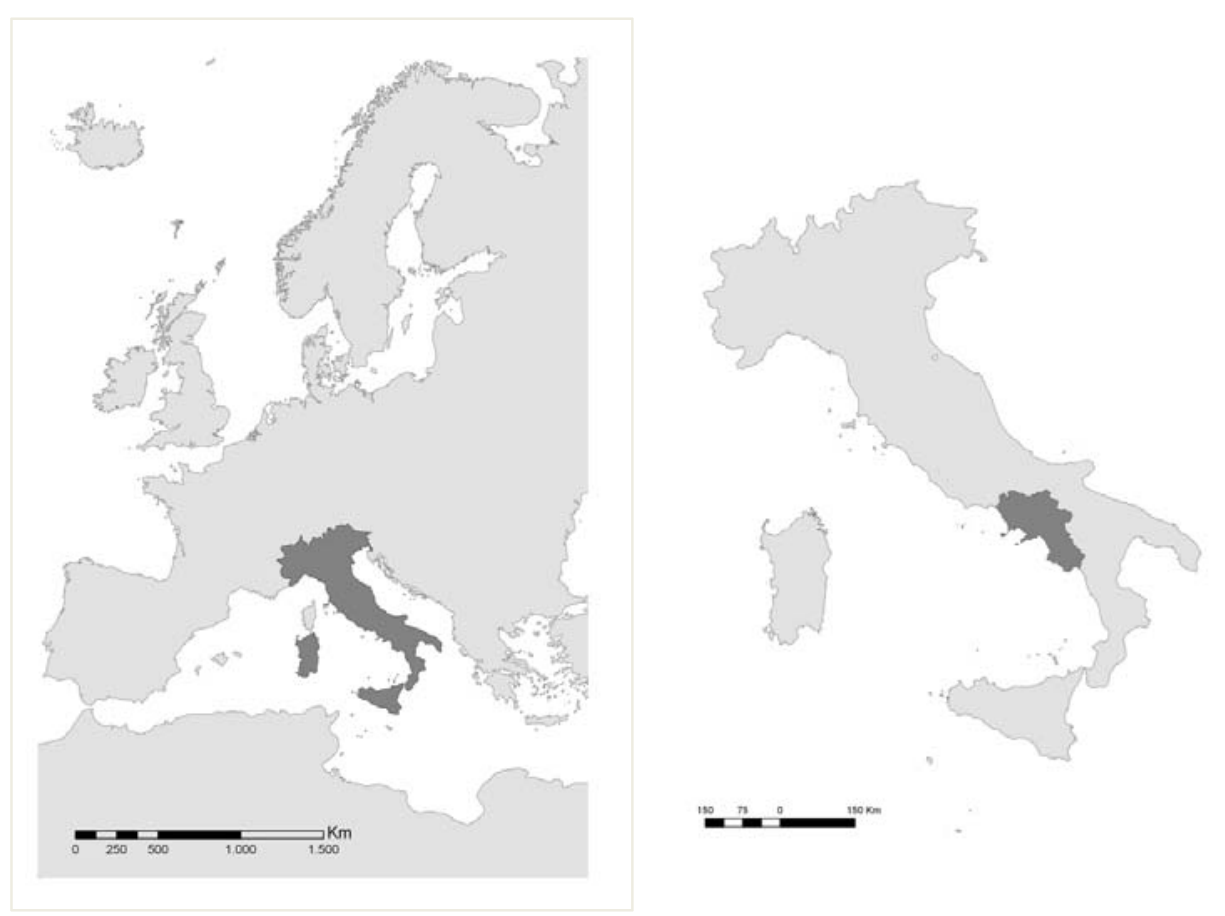

Figure 1: Geographical position of Campania Region. Source: elaborated by D. Burgalassi, 2010.

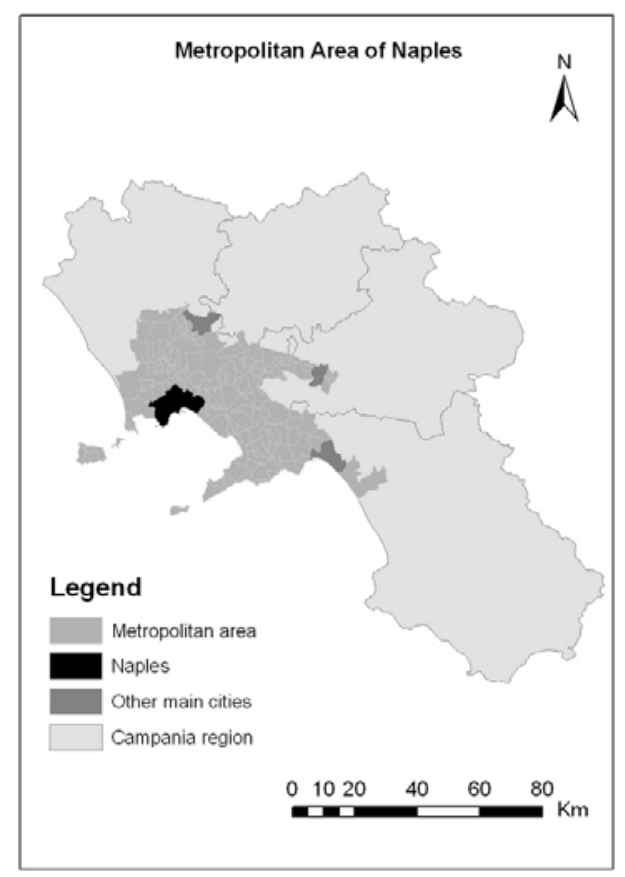

Figure 2: Metropolitan area of Naples. Source: elaborated by Burgalassi using SVIMEZ data, 2010. 


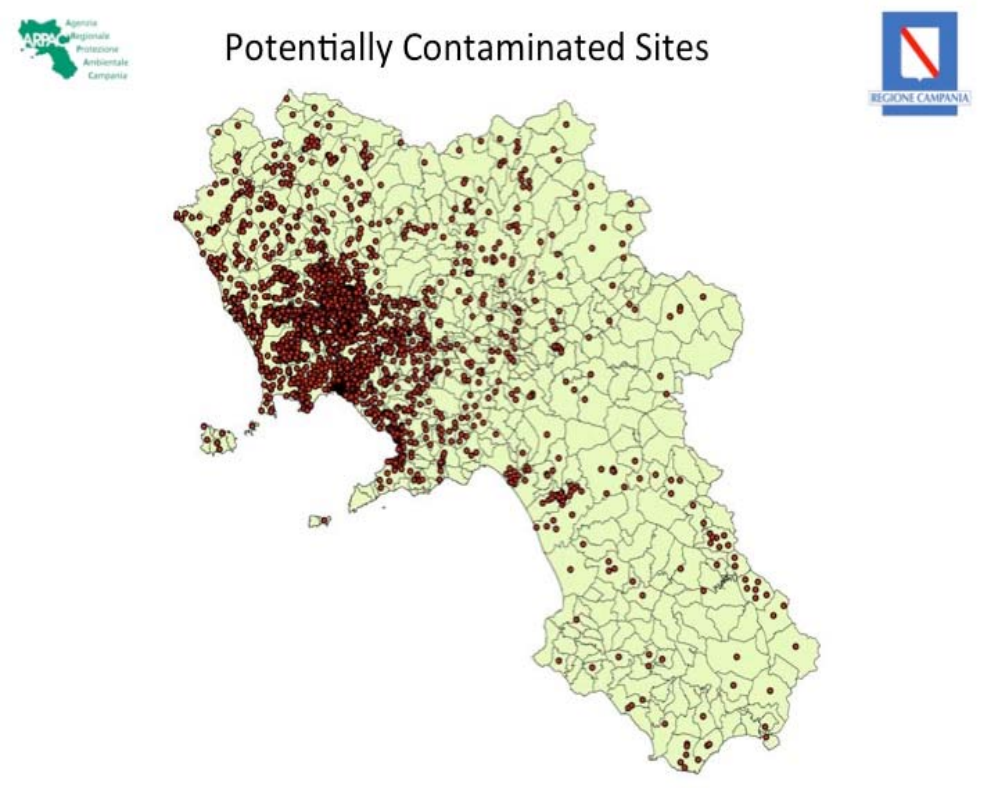

Figure 3: Potentially contaminated sites in Campania. Source: elaborated by D'Alisa (2010) on a map produced by ARPAC.

Six months of fieldwork took place in Campania, in particular in those municipalities that fall in the perimeter of the LoF as defined by the national government (see Figure 4). From August to December 2014, the first author participated in demonstrations, assemblies, local marches, seminars and meetings organized by grassroots movements and NGOs, which are fighting against illegal burning and burying of waste in the Campania region. Thirty-four face-to-face semi-structured interviews were conducted with opinion leaders ${ }^{7}$, who were part of the archipelago of associations that emerged out of the twenty year long environmental conflicts in Campania. The sample of interviewees was built through a snowball technique. We started by interviewing three classes of activists:

(1) those that act as "the face" of the local mobilization in regional and national media (newspapers and broadcast media);

(2) those who appealed to the President of the Italian Republic;

(3) those who took legal action to denounce the serious environmental conditions in the $\mathrm{LoF}$ and the consequent negative impacts for human health.

Then, we asked each activist interviewed to suggest other names and contacts that, according to them, were relevant in the Campania waste struggle. The interview questionnaire consisted of four parts and was designed to provide:

(1) General information about the respondents (i.e. age, education, employment, etc.);

(2) Information about environmental behavior and attitudes of the people interviewed, their level of engagement in grassroots activities for combating waste trafficking and mismanagement, and their self-perception as victims of environmental crime;

(3) Information on the kinds of relationships that, as activists, they have with informal and formal institutions, such as local associations and grassroots committees (e.g.

\footnotetext{
${ }^{7}$ Not all individuals exert an equal amount of influence over others. In this sense, opinion leaders are influential in spreading positive or negative information about a particular issue. Rogers (1962) emphasized the role of opinion leaders in influencing late adopters during the evaluation stage of the innovation-decision process.
} 
$29^{\text {th }}$ August Committee, Campania Network for Health and Environment, Fires Coordination Committees, etc.); regional, national and international NGOs (e.g. Legambiente, Italia nostra, Rete Lilliput, WWF, Greenpeace, ISDE - International Society of Doctor for the Environment, etc.); research and health centers (e.g. CNRResearch National Center, ENEA - National Body for Energy and Environment, WHO -World Health Organization); and public authorities (e.g. Commissioner for Waste Emergency in Campania, the Department of Civil Protection, Prefects, etc.). ${ }^{8}$ We investigated the existing ties across what we consider to be the turning point of the waste struggle in Campania; ${ }^{9}$

(4) We developed open questions on how the activists defined the environment, what kinds of actions they considered an environmental crime and what does it means personally to be victims of such offences? With the help of five selected and previously trained interviewers, some 85 interviews were conducted in two main demonstrations that occurred in 2014 in Naples and in Casal di Principe, a small city in the province of Caserta, which is well known for the presence of a powerful camorra family. The demonstrations involved thousands of people; the selection of the interviewees was random but balanced by gender.

Finally, 120 interviews were conducted. We present descriptive statistics on the interviewees to identify key determinants of their self-perception of victimhood (Table 1,2).

\section{The Probit model}

An ordered, discrete choice Probit model was run to estimate the probability of a respondent being a victim, as a function of a waste-related environmental characteristic.

Let us put the linear relationship as $\mathrm{Y}=\mathrm{f}(\mathrm{x} 1, \mathrm{x} 2, \ldots, \mathrm{xn})$, where $\mathrm{Y}$ represents the people's selfperception of being a victim and $x i$ is a single factor potentially explaining it. Taking into account this relationship, the linear probability model is based on the linear regression:

$$
\mathrm{Yi}=\mathrm{Xi} \beta+\varepsilon i(1)
$$

where $\mathbf{Y}$ represents the dependent variable categorised into five levels and is coded $(1=$ very high perception of not being a victim, 2 = high perception of not being a victim, 3 = uncertain perception of being a victim, $4=$ high perception of being a victim, and $5=$ very high perception of being a victim). Then, $\mathbf{X}$ is a matrix of independent variables $(\mathbf{N} \times \mathbf{K})$ that embodies the set of factors $\mathbf{x}$ while $\boldsymbol{\beta}$ is the estimated vector $(\mathbf{K} \times 1)$, $\mathbf{i}$ is referenced to the single respondent in the sample and $\boldsymbol{\varepsilon}$ is the stochastic error (Cameron and Trivedi, 2005). With the assumption that the error $\mathbf{\varepsilon i} \mid \mathbf{x i}$ is distributed as a standard normal, $\boldsymbol{\varepsilon} \approx \mathbf{N}(0,1)$, the probability of obtaining the corresponding value $\mathbf{i}$, is then given by:

$$
P(Y=j \mid X i)=P\left(Y i^{*}>0 \mid X i\right)=\Phi\left(X i^{\prime} \beta\right)(2)
$$

where $\mathbf{P}$ is the probability of observing the event $\mathbf{j}$ and $\boldsymbol{\Phi}$ is the standard normal cumulative density function.

In order to obtain a consistent estimate of parameters, the method of maximum-likelihood is used. Consequently, the coefficient estimated $\beta$ for the determinants are to be interpreted as the increased probability of feeling a victim compared to a "not feeling a victim" status.

\footnotetext{
${ }^{8}$ The interviewees were also free to suggest different organizations from those listed.

${ }^{9}$ We set 2008 as the turning point for two main reasons. First, at the end of 2007 and the beginning of 2008, tons of waste was piled in the streets and the images of those mountains of garbage on the roads, submerging Naples and tens of surrounding municipalities, were circulated all around the world by different media. Second, in 2008 , the national government issued Decree 90/2008 (converted into Law 123/2008), which imposed ten landfills and four incinerators on Campania and established that any demonstrations in the vicinity of a waste facility would be judged as a penal felony. For some years this weakening the grassroots waste movements in the region.
} 
We fitted the model using a backward stepwise procedure, in which the definitive variables considered in the model are the results of a screening activity of the initial saturated list of variables. Starting from a model with all possible explanatory variables, its fit was tested after the elimination of each variable. In this way, the evaluation of the best model is done according to an ability to fit the data through a matrix of correlation. The removal of a variable is able to vary the likelihood ratio chisquare $^{10}$, which is the parameter used to verify the degree of fit of the model. When the elimination of another variable leads to a decreased likelihood ratio, the analysis is complete and it is not possible to delete further variables.

The independent variables considered as determinants of people's self-perception of being a victim, are listed in Tables 1 and 2. The determinants were merged into two main categories, namely interviewee general features, and their personal experiences of environmental issues. Within the former category there are four variables related to respondent features such as gender, age, education level and current employment status (i.e., employed or not). For the latter, eight possible explanatory variables of the victim's self-perception are taken into account. In particular:

(1) "env_qual" reflects the respondents' ideas of the quality of the environment in which they are living;

(2)"env_health" express the point of view of the respondents about the link between the health and the quality of the environment in which they are living;

(3)"lifestyle" express the point of view of the respondents about the link between the health and lifestyle;

(4) "waste_disp" describe the perception of the interviewee of living in the vicinity of a legal waste treatment plant and/or an illegal waste disposal;

(5)"ist" and "ist_loc" represent the respondent's stated trust towards political institutions at general (i.e., European, national and regional) and local levels;

(6) "illness" denotes some serious contracted diseases (i.e. such as asthma, respiratory difficulties, disorders of the circulatory system, cancer, etc.) by the respondent, by its family or friends;

(7)"pol_engag" reveals interviewee's membership of a political party and/or environmental associations.

\begin{tabular}{lccc} 
Obs. & Code & Variable description & Coding \\
\hline 120 & gender & Sex of the respondent & $1=$ female, $2=$ male and $3=$ other \\
120 & age & Age of respondent (years) & $<25,25-40,40-50,>50$ \\
120 & education & Education level of respondent & None, Primary school, Secondary school, \\
120 & employment & Employments status & University degree, Ph.D. \\
\hline
\end{tabular}

Table 1: General features of those interviewed.

\footnotetext{
${ }^{10}$ In econometric, a likelihood ratio test (chi-square) is a statistical test used to compare the goodness of fit of two models, one of which (the null model) is a special case of the other (the alternative model). The test is based on the likelihood ratio, which expresses how many times more likely the data are under one model than the other.
} 


\begin{tabular}{|c|c|c|c|}
\hline Obs. & Code & Variable description & Coding \\
\hline 120 & env_qual & Good environmental quality & $\begin{array}{c}1=\text { agree; } 2=\text { neither } / \text { nor; } \\
3=\text { disagree }\end{array}$ \\
\hline 120 & env_health & $\begin{array}{c}\text { Health depends directly on quality of the } \\
\text { environment }\end{array}$ & $\begin{array}{c}1=\text { agree; } 2=\text { neither } / \text { nor; } \\
3=\text { disagree }\end{array}$ \\
\hline 120 & lyfestyle & Health depends directly on people's diet & $\begin{array}{c}1=\text { agree } ; 2=\text { neither } / \text { nor; } \\
3=\text { disagree }\end{array}$ \\
\hline 120 & illness & $\begin{array}{l}\text { Serious contracted diseases } \\
\text { (itself - family - friend) }\end{array}$ & $0=$ yes, $1=$ no \\
\hline 120 & waste_disp & Living close to a waste treatment plant & $0=$ yes, $1=$ no \\
\hline 120 & ist & $\begin{array}{c}\text { Confidence with political organisations at } \\
\text { different levels }\end{array}$ & $0=$ yes, $1=$ no \\
\hline 120 & ist_loc & Confidence with local institutions & $0=$ yes, $1=$ no \\
\hline 120 & pol_engag & $\begin{array}{c}\text { Being a member of a political party and/or } \\
\text { environmental associations }\end{array}$ & $0=$ yes, $1=$ no \\
\hline
\end{tabular}

Table 2: List of variables used as determinants.

\section{Situating victims' perception of waste-related Environmental Crime}

Campania, the icon of urban waste mismanagement

During the 1980s, many industrialised countries started to tighten their domestic waste-related regulations because of increasing international concerns about the potentially harmful effects of waste trafficking (La Rocca, 2014). However, stricter laws were not an effective deterrent; instead they contributed towards making illegal disposal of more and more industrial waste more lucrative. In the 1990 s, the illegal waste business in Italy thrived; ${ }^{11}$ the freemasons, part of the state apparatus and camorra themselves, orchestrated a powerful network able to illegally dispose of millions of tons of waste per year (Iacuelli, 2008). In 2000, the first official account estimated the business was worth around $€ 7.5$ billion ( $\$ 7.4$ billion) per year, with a loss for the treasury of $€ 1$ billion (\$1.06 billion) every year (Scalia, 2000). Nowadays, it is worth almost $€ 17$ billion ( $\$ 18.06$ billion) (Legambiente, 2013). In fifteen years the turnover more than doubled. Several strategies are used to illegally dispose of the industrial waste, such as:

a) dumping hazardous waste directly in the countryside;

b) dumping hazardous waste in illegal quarries and the construction sites for public infrastructural works;

c) burning special waste in the countryside and along low-traffic roads, and;

\footnotetext{
${ }^{11}$ According to the Parliamentary Commission of Inquiry on the Waste Cycle and Connected Illicit Activities (PCIWCCIA), every year almost $30 \%$ of national special waste is illegally disposed of (Scalia 2000: 7). Considering that Campania businesses produce only a small amount of national special waste (see next footnote), most of the waste illegally disposed of in Italy is produced by enterprises located in other Italian regions.
} 
d) mixing toxic with domestic waste for disposal in legal landfills and incinerators (Barbieri and Paglionica, 2007; Fontana et al., 2008; Iacuelli, 2008; Scalia, 2000).

Campania has become the main zone targeted for such strategies and the biggest destination for illegal dumping in Italy. ${ }^{12}$ The impact of such business has been politically, economically and ecologically disastrous for the entire region. In the 1990s prosecutors tried to stop the flourishing waste traffic by shutting down some landfills, because of their precarious sanitary conditions. The main consequence of those law enforcement actions was the interruption of urban waste collection, with almost no proven effects on the illegal practices themselves. The diminishing capacity of legal landfills (D'Alisa and Armiero, 2011), and the absence of a regional waste management plan was the justification in 1994 for the national government to declare a state of emergency for the Campania region and to delegate waste management to an ad hoc Commissioner (Armiero and D'Alisa, 2012). The government focused its authoritarian intervention on urban waste and completely dismissed the mounting and more problematic issue of the illegal dumping of hazardous waste. The state of emergency regime caused an increase in civil unrest and facilitated the proliferation of the camorra's businesses, which also infiltrated urban waste management. It caused a crisis of democracy in Campania (D'Alisa et al., 2010). Only with the resurgence of the local grassroots movement in 2012, after the end of the waste emergency had been declared three years earlier, did the Land of Fires become visible (again).

\section{The Land of Fires: the emblem of illegal disposal of waste}

In Italy over the last 30 years, mafia families have increasingly been involved in environmentally disruptive businesses. The waste business is very lucrative while the sanctions are very loose (Persi, 2014). No other business offers this double incentive. The "Ecomafia" identifies those mafia organizations that have infiltrated areas through waste trafficking, unauthorised construction, the cement cycle and illegal mining, forest fires and arson, trafficking of wild animals, agro investments, and trading in archeological artifacts. This is a series of very different businesses compared to the traditional mafia interests in trafficking drugs, armies and people. The role of organised mafia-like crime in these new activities is certified by the tens of dossiers about the ecomafia that Legambiente, one of the most well-known environmental NGOs in Italy, has been producing since $1997 .{ }^{13}$

The term Land of Fires was used for the first time in a Legambiente dossier in 2003 (Legambiente, 2003). Legambiente staff coined the term LoF to indicate an area of the municipalities of Giugliano in Campania, Qualiano and Villaricca in the province of Naples where, since the 1980s, thousands of tons of toxic waste have been illegally buried and burnt. Italian citizens started to be familiar with LoF after the publication of Gomorra (Saviano 2006), a best-selling book that describes the businesses of the camorra as an organised criminality able to interweave a web of local interests and play a key role in the Italian economy as well as abroad. In 2007, an activist from Villaricca in Campania created a website called the LoF and, since then, new videos are uploaded everyday on this very popular online platform. They record the columns of toxic smoke generated by illegal burning. Currently, more than 800 toxic smoke sightings have been mapped. ${ }^{14}$ In recent years, several grassroots committees were born and many of them joined a social coalition called Stop Biocide, ${ }^{15}$ which denounces the illegal trafficking of industrial waste in Campania, the mounting contamination of air, aquifers, soil and subsoil, and the increase of cancer diseases and mortality in the area.

\footnotetext{
${ }^{12}$ Campania generates a small amount of industrial waste compared to the rest of Italy, not only in absolute terms, but also relative to its contribution to the national GDP. For example, in 2009 the production of special waste in Italy was about 134 million tons, of this more than 10 million tons were hazardous $(7.5 \%$ of the total production). Campania produced slightly more than 6.4 million tons, of which 0.35 million were hazardous (5.8\% of the regional production) (ISPRA, 2012). It means that Campania generates only $4.7 \%$ of the total special waste in Italy and only $3.5 \%$ of the national production of hazardous waste, even if the contribution to the national GDP is $6.25 \%$ (http://sitis.istat.it/sitis/html/).

${ }^{13} \mathrm{http}: / /$ www.legambiente.it/contenuti/dossier/rapporto-ecomafia

${ }_{14}$ The map is available at http://www.laterradeifuochi.it/. Last visit: $12^{\text {th }}$ August 2014.

${ }^{15}$ https://it-it.facebook.com/stopbiocidio
} 


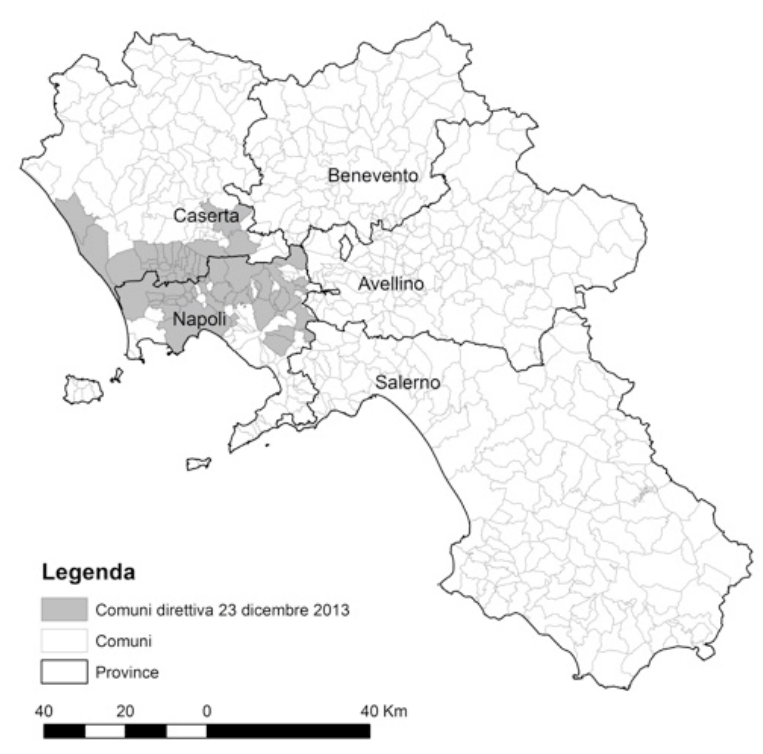

Figure 4: The Land of Fires.

The clamor about the LoF exploded after a declaration by the informant Carmine Schiavone, an ex-affiliate of the camorra (a prominent boss of the Casalesi, one of the most powerful Campania clans). In 2009, his protection programme, which is guaranteed to all informers by the Italian State, ended. Since then, several journalists working for local and national newspapers ${ }^{16}$ and media broadcasters ${ }^{17}$ have interviewed him (Di Chio and Martini, 2009). The former Casalesi boss revealed links between politicians and the mafia and spoke about the economic interests of his family and the huge amount of money they gained from the illegal toxic waste dumping business. In 2013, his 1997 hearing with the Parliamentary Commission was declassified and was widely covered by the media. Despite politicians', journalists' and activists' criticism of Schiavone for his alarmism and colourful interviews (LivioTV ${ }^{18}$; Musella, 2013 ${ }^{19}$; Televomero broadcast $2014^{20}$ ), no one denied that his stories contributed to spreading news of the seriousness of the situation in the LoF. The media coverage contributed to more citizen participation in local demonstrations. Several massive popular protests at the end of 2013 prompted the national government to issue Law Decree 136/2013, converted to Law $6 / 2014$ a few months later. With this law, the national government recognized the extreme seriousness of the environmental, health and economic conditions of many municipalities in Campania, and declared the illegal burning of toxic waste a crime. Furthermore, the national government committed to a) investing money and resources in mapping the agriculture territory in the region in order to control and prohibit cultivation in the most contaminated areas, and b) coordinating the necessary interventions for land reclamation.

The recognition at the national level of the importance of a coordinated intervention to stop the toxic smoke started in 2012 when the Minister of Internal Affairs appointed a special commissioner to survey waste burning in Campania. ${ }^{21}$ Their task was to steer the work of the police, the prefectures of Naples and Caserta and other authorities (Decree 12/11/2012). However, only with the passing of Law 6/2014 was the LoF area institutionalized and the intervention systematized. In 2013, the national

16 Il Tempo, http://www.iltempo.it/cronache/2012/12/12/parla-il-pentito-schiavone-br-ecco-la-vera-gomorra1.206464, last accessed 12 August 2014.

${ }_{17} \mathrm{http} / / / \mathrm{vide}$.sky.it/news/cronaca/schiavone a skytg24 non mi pentirei di nuovo/v168746.vid; http://www.serviziopubblico.it/2013/12/24/news/parla carmine schiavone.html

$18 \mathrm{https}: / /$ www.youtube.com/watch?v=6QowyoN-o_E

${ }^{19} \mathrm{http}: /$ www.fanpage.it/terra-dei-fuochi-massimo-scalia-giorgio-napolitano-2/

${ }^{20} \mathrm{https}: / / \mathrm{www}$.youtube.com/watch? $\mathrm{v}=\mathrm{iBX}-\mathrm{VwX} 8$-eA\&feature=youtu.be

${ }^{21}$ Spagnolo 2012, Lotta ai roghi tossici c'è un commissario, www.avvenire.it/Cronaca/Pagine/roghi-tossici-lamossa-del-commissario.aspx 
government ${ }^{22}$ had extended the LoF to $1,076 \mathrm{~km}^{2}$, which consists of 57 Municipalities: 33 in the Province of Naples and 24 in the Province of Caserta (Figure 4). Moreover, I maintain that the LoF should be interpreted as more than a geographical area; more importantly it is a symptom of illegal waste dumping implemented to cut waste disposal costs for legal and illegal businesses. Thus, the phenomenon is not contained within a strict perimeter and can be explained only through processes operating at larger scales. ${ }^{23}$ Indeed, in 2014, the government broadened its investigations, and commissioned a technical investigation to verify the contaminating effects of illegal disposal in 88 municipalities in Campania. ${ }^{24}$ Furthermore, since 2012 more and more municipalities have been asking to be part of the Pact for the LoF, i.e. a memorandum of understanding among several municipalities and the Commissioner for the prevention of waste burning in order to promote coordinated activities of control, prevention and repression of the illegal disposal of waste. ${ }^{25}$

\section{The role of organised crime in waste trafficking}

The role of organised crime in the Italian waste trafficking business has also been revealed by many of those affiliated with mafia organisations, which significantly contributed to launching criminal investigations related to waste. The first famous informer was Nunzio Perrella, brother of a powerful boss of a neighbourhood in Naples. In 1992, he declared that "waste is gold", indicating why organized crime has been gaining increasing interest in the waste business since 1988. Collaborating with prosecutors, he offered a first map of the main eco-criminals in Campania and the connections they had with enterprises in northern Italy, which needed the help of organised crime to get rid of the waste they produced. In the mid 1990s, as mentioned previously, the boss of Casalesi, Carmine Schiavone also started to collaborate. During his hearing, in 1997, with the Parliamentary Commission on Waste Cycle and the Connected Illicit Activities, he filed detailed documentation of the Casalesi's interests in waste trafficking. He depicted the network of actors that made money out of waste; just for his clan the turnover was about $€ 300,000$ (US\$316,000) per month. ${ }^{26}$ However, the same Commission in the final report in 2000 recognized that blaming only mafia-like organizations for illegal waste trafficking was a big error. Legal businesses with no criminal clan associations have a very important role in the illegal trafficking of waste. Indeed, the camorra is a key actor in an intricate web of legal entrepreneurs and governmental officers that have secured a cheap dumpsite for:

1) myriads of small illegal business in the Campania region;

2) hazardous waste from northern Italy; and

3) other toxic waste coming from other European countries (Scalia, 2000). ${ }^{27}$

Despite public opinion being that organized mafia-like crime is responsible for the illegal trafficking of waste, authorities have been trying to emphasize that corporations with no relation to mafia organizations commit waste-related environmental crimes much more often (de Falco, 2014). The state's attorney, Franco Roberti who interrogated Nunzio Perrella at the beginning of the 1990s and is now the National Anti-mafia Prosecutor, tirelessly supports the view that waste related crimes are primarily corporate crimes. ${ }^{28}$ Also Giuseppe Peleggi, director of the Customs and Monopoly

\footnotetext{
${ }^{22}$ Ministerial Directive $23^{\text {rd }}$ December 2013. Available at:

http://www.salute.gov.it/portale/news/p3 2 3 1 1 1.jsp?lingua=italiano\&menu=dossier\&p=dadossier\&id=36

${ }_{23}$ The phenomenon is not restricted to the Campania region. It is a national and an international occurrence.

${ }^{24}$ Ministerial Directive $16^{\text {th }}$ April 2014. Available at:

http://www.salute.gov.it/portale/news/p3 2 3 _ 1 1 j.jsp?lingua =italiano\&menu=dossier \&p=dadossier\&id=36

${ }^{25}$ For an updating of the list of participants to the Pact for the Land of Fire, visit: http://www.utgnapoli.it/public/roghi2013/cabina_regia_2014.php

${ }^{26}$ Hearing with camorra informer Carmine Schiavone. Parliamentary Commission on the Waste Cycle and Connected Illegal Activities; XIII legislature.

${ }^{27}$ Scalia (2000). File on illicit trafficking and Ecomafie. Parliamentary Commission on the Waste Cycle and Connected Illegal Activities; Doc. XXIII No 47. Available at: http://legislature.camera.it/ bicamerali/nochiosco.asp?pagina=/ bicamerali/rifiuti/home.htm

${ }^{28}$ Hearing with National Anti-Mafia Prosecutor Franco Roberti. Parliamentary Commission on the Waste Cycle and Connected Illegal Activities; XVII legislature.
} 
Agency, the most important public institution that fights cross-border waste traffic in Italy, said that the poor sanctions against corporations means that agency officers cannot punish them. This was during his November 2014 hearing for the Parliamentary Commission. For example, he said he discovered a Chinese corporation illegally trafficking waste four times in the same year, but he could not stop their operations. The same firm often commits the same crime in different Italian harbors and each time agency officers arrest the legal representative, but they cannot halt the business itself. ${ }^{29}$ Finally, Roberto Pennisi, prosecutor of the Ecomafia section of the National Anti-mafia District, ${ }^{30}$ ascertained that the environmental disaster that occurred in Campania was not created by the camorra, which basically offered a service to all business actors who wanted to lower the price of waste disposal. These findings are in line with Europol's assessment of illegal waste practices in Europe. Illegal waste trafficking generates high profits and it is a low risk activity, which the organized mafialike groups and legal companies both engage in; the latter increasingly asking the former for illicit disposal services in all European Member States (Europol, 2013).

\section{Epidemiology and waste disposal in Campania}

There is a longstanding debate about the correlation between the presence of legal and illegal waste facilities and dumps, and the increasing mortality and morbidity rates for different diseases. According to some scholars, the illegal disposal of toxic waste can contaminate land and water sources causing biological alterations that could affect the entire ecosystem (Rajaguru et al., 2003). Moreover, organisms inhabiting areas with effluent discharges can suffer genetic damage, and humans using polluted water are also at risk of similar genotoxic effects (Stahl, 1991). As confirmed by a study done by Maselli et al. (2010), in some areas of Campania where waste misconduct has occurred, a specific species of frog suffered severe DNA damage. ${ }^{31}$ The effect of incineration on human health has also been discussed. In the 1990s, some scholars suggested that men living near a municipal solidwaste landfill site in Montreal were at a higher risk of developing cancer (Goldberg et al. 1995, 1999). More recently, in Italy several studies have shown that living close to a waste incineration plant will increase the incidence of cancer. Comba et al. (2003) found that living within a $2 \mathrm{~km}$ radius of an industrial waste incinerator in Mantua (Italy) was associated with a significant increase in risk of softtissue sarcomas. Parodi et al. (2004) looked at lung cancer mortality in two regions of northern Italy exposed to environmental pollution emitted by a coal-fired power station and other industrial sources, including a waste incinerator. The results suggested a pollution related risk for the women, but in men the results were confused by occupational exposure and a greater tendency to smoke.

Senior and Mazza (2004) were among the first to speculate about the link between the high level of cancer mortality in an area of the province of Naples and the level of pollution caused by illegal waste disposal; an area that the two scientists came to call the "triangle of death." Even though their report was criticized for not being sufficiently rigorous (Bianchi et al., 2004; Terracini, 2004), the "triangle of death" became a reference for many grassroots activists when it came to denouncing the health risk of living in some areas of the Campania region (D'Alisa et al. 2010). In 2004, the results of another study showed the increase in cancer mortality in the LoF area; however the authors clarified that in order to better describe the health consequences of the environmental burden in the area, new and more precise studies were needed (Altavista et al. 2004).

Under the pressure of social unrest in Campania, which lobbied State authorities to verify the impacts that the waste cycle has on health in the hot-spots of the region, the Civil Protection Department commissioned the World Health Organisation to conduct an epidemiological study. The results showed high rates of mortality from all causes and for specific cancers in 24 municipalities between the province of Caserta (11) and the province of Naples (13). However, the scientists were more than cautious about correlating this with proximity to waste facilities (legal and illegal). On the

\footnotetext{
${ }^{29}$ Hearing with the executive director of Customs and Monopoly Agency. Parliamentary Commission on the Waste Cycle and Connected Illegal Activities; XVII legislature.

${ }^{30}$ Since 2010 (art. 11 Law 136/2010) the National District of Anti-mafia has the responsibility of prosecuting all the criminal activities in violation of art. 260 (Legislative Decrees 153/2006), the norm that sanctions the organized illegal trafficking of waste.

${ }^{31}$ Maselli et al. (2010) investigated the edible frogs' erythrocytes, which are considered a good bio-indicator for detecting genotoxic effects of chemical environmental hazards.
} 
contrary, according to them, the main determinants of such high rates were poor lifestyles and occupational exposure of Campania citizens (bad diet, smoking tobacco and infections). Moreover, the presence of other intensive industrial and agriculture activities in the area confounded any precise correlation (Martuzzi et al. 2005). Other studies followed and detected anomalies in health conditions in those municipalities in Campania where illegal disposal of waste was more frequent, but they also confirmed the lack of causal relationships between the mortality and morbidity rates, and the presence of waste malpractices (Fazzo et al., 2008). Recent studies commissioned by the national government reaffirm that the causal link between health and illegal waste dumping is not demonstrable (Capocaccia et al., 2012). Meanwhile, international observers have settled on the lifestyle explanation (see Abbott, 2014); however, this does not explain why thousands of sheep in the province of Naples have been slaughtered due to contamination, even if they neither smoke cigarettes nor drank alcohol (D'Alisa et al., 2014).

\section{The determinants of victims' self-perception: empirical results}

The lack of causality in scientific studies is not reflected in the perceptions of local residents, to which we now turn to understand sources of anxiety and activism in the region. The one hundred and twenty respondents to our survey questions were $43 \%$ men, $54 \%$ women and $2.5 \%$ other (Table 3 ), with an average age of 38 , the youngest being 18 and the eldest 68 . The number of family members is on average 3 , more than $35 \%$ hold a bachelor degree with almost $7 \%$ of them having also a Ph.D.

\begin{tabular}{l|ll}
$\begin{array}{l}\text { 3a. } \\
\text { Gender }\end{array}$ & No & $\%$ \\
\hline Male & 52 & 43.3 \\
Female & 65 & 54.2 \\
Other & 3 & 2.5 \\
\hline Total & $\mathbf{1 2 0}$ & $\mathbf{1 0 0}$ \\
\hline
\end{tabular}

\begin{tabular}{l|ll}
$\begin{array}{l}\text { 3b. } \\
\text { Age }\end{array}$ & No & \% \\
\hline$<\mathbf{2 5}$ & 23 & 19 \\
$\mathbf{2 5 - 4 0}$ & 53 & 44 \\
$\mathbf{4 0 - 5 0}$ & 26 & 21 \\
$>\mathbf{5 0}$ & 18 & 16 \\
\hline Total & $\mathbf{1 2 0}$ & $\mathbf{1 0 0}$ \\
\hline
\end{tabular}

\begin{tabular}{l|ll} 
3c. Education & No & \% \\
\hline None & 0 & 0 \\
Primary school & 50 & 41.7 \\
Secondary school & 18 & 15 \\
University degree & 44 & 36.6 \\
Ph.D. & 8 & 6.7 \\
\hline Total & $\mathbf{1 2 0}$ & $\mathbf{1 0 0}$ \\
\hline
\end{tabular}

Tables 3 a, b, c: General statistics for the respondents: gender, age and highest level of formal education.

Almost $100 \%$ of the respondents believe (almost $80 \%$ strongly believe) that the health of people crucially depends on the quality of the environment in which they live, and $83 \%$ of them declared that environmental quality in the place where they live is bad (See Figure 5a and 5b). For $73 \%$ of the respondents ('strongly agree' $23 \%$ plus 'agree' $50 \%$ ) (Figure 5c), another relevant variable that affects the health status of people is their lifestyle, i.e., the diet they follow, the number of cigarettes they smoke, and the quantity of alcohol they drink. Central to the aim of this article is the result represented in Figure 5d: $97.5 \%$ of the respondents feel that they are the victim of an environmental crime ( $79 \%$ of them 'strongly agree' with that question).

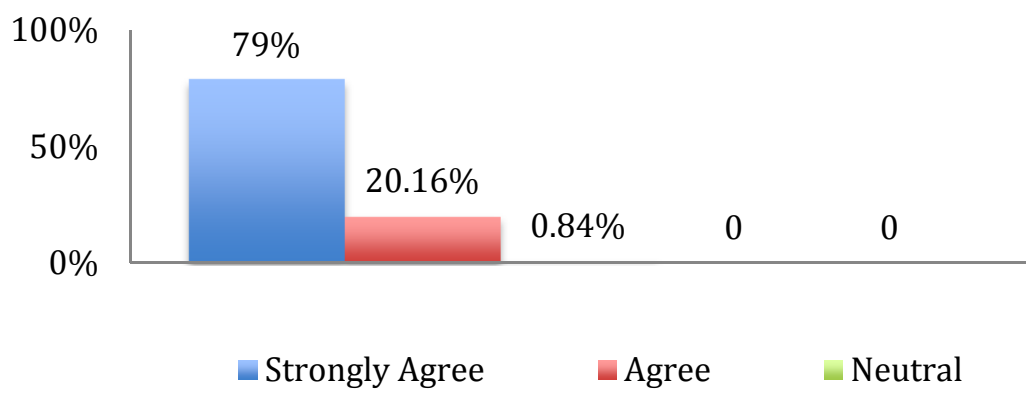

Figure 5a: People's health depends directly on the environmental quality of the place in which they live. 


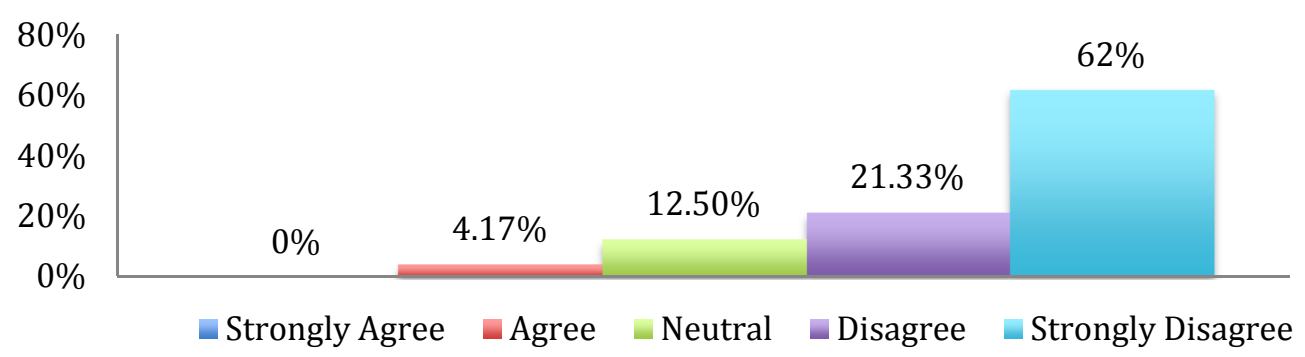

Figure 5b: The environmental quality of the place you live in is good.

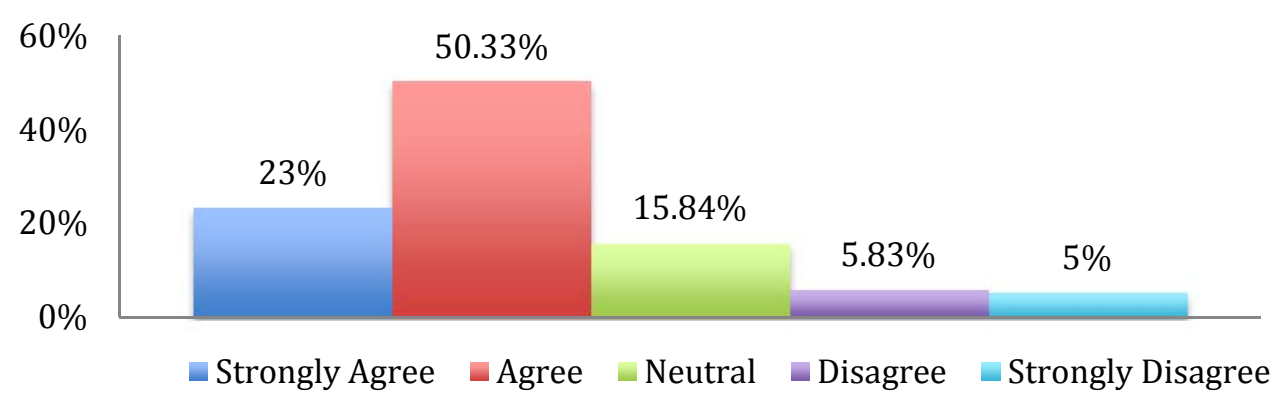

Figure 5c: Health depends directly on people's diet, on the quantity of alcohol consumed and on the quantity of cigarettes smoked

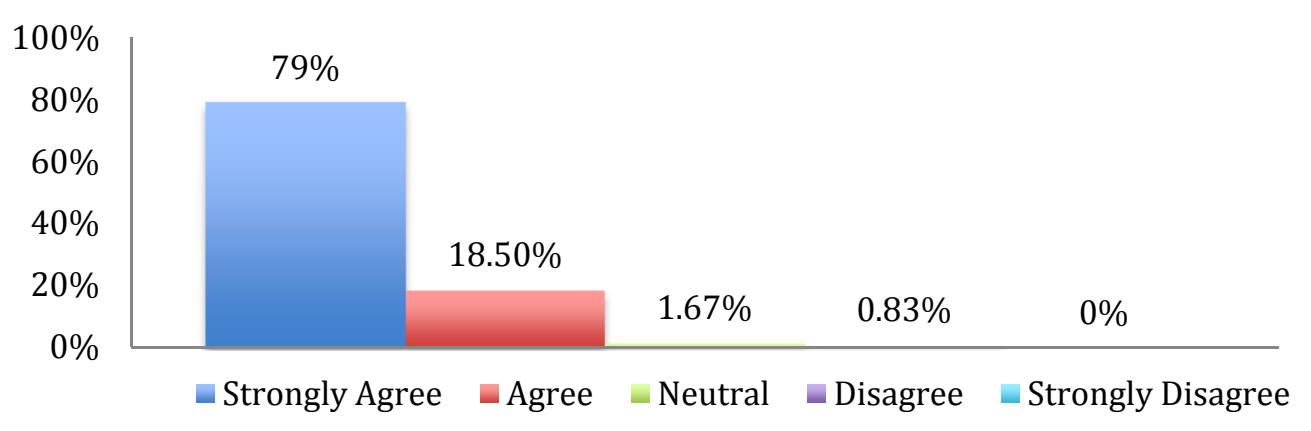

Figure 5d: Do you feel a victim of any environmental problems affecting your city, province or region?

Some $26.5 \%$ of those interviewed said that, in the last decade, they had been affected by serious diseases such as cancer, asthma, general respiratory difficulties, and disorders of the circulatory system (see Figure 6). Some $64.71 \%$ had at least one close relative who has been (or is) ill or died because of one of the above listed diseases. Finally, the vast majority of the sample $(81.67 \%)$ has a friend that has been (or is) ill or has died for the same reasons. However, they define their status of being victims as something determined by a physiological state of mind that forced them to live in continuous uncertainty about the quality of the food they eat, the water they drink and the air they breathe. As a series of answers testify: 
[Being victim of environmental crime] means being helpless (ID\#41) ... to be powerless to face a 'fait accompli'(ID\#42) ... to feel refused your own freedom to live (ID 56) ... implies that I cannot decide my future, and (that I have) to live always with fear (ID57) ... to be condemned for an indefinite period of time (ID63) ... to fear what you eat, or you drink without having the possibility to do precautionary analysis...

Uncertainty, accompanied by frustration due to the difficulty of identifying a single culprit, and the feeling of being abandoned to their destiny by politicians that counts at different levels of government is another diffused feeling, as this respondent puts it:

[Being a victim of environmental crime] implies beings humiliated by institutions) ... means not being defended by the appointed institution, which should, instead, intervene with preventive and punitive actions... (ID\#45)

$\square$ Friend serious diseases $\square$ Family member serious diseases $\quad$ Personal serious diseases

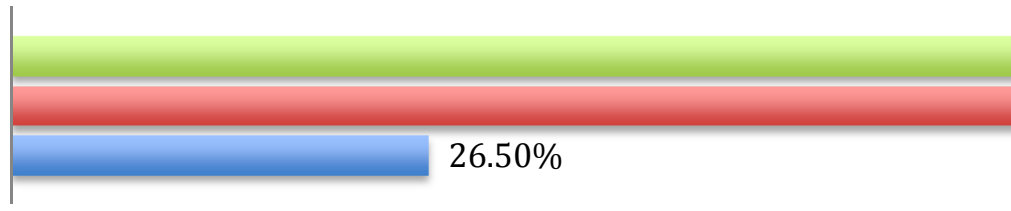

$64.71 \%$

Figure 6: Occurrence of serious diseases at personal, family and friend level

It is not by chance, therefore, that $66 \%$ of the respondents declare that they have no trust in political institutions (Figure 7). Perception of the culprits is shown in Figure 8.

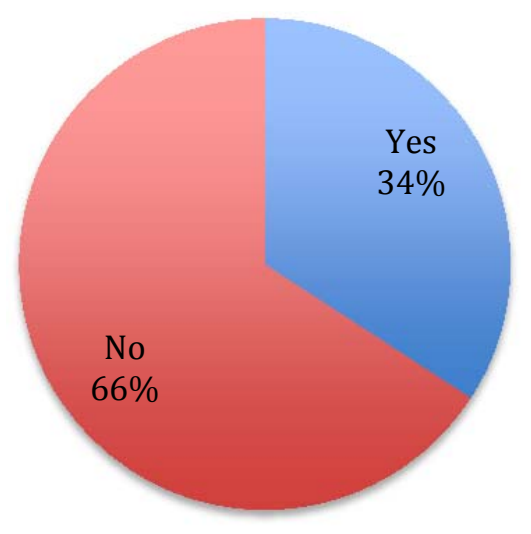

Figure 7: Trust of respondents in political institutions.

The illegal burning of waste is perceived as the critical environmental problem close to respondents' homes (84.17\%) (Figure 9). Concerns were equally present over landfill mismanagement $(80.33 \%)$, and also the incinerator $(64.16 \%)$. Other environmental issues mentioned in the survey were the presence of heavily polluting industries, marine pollution, and transport and traffic problems (see). 


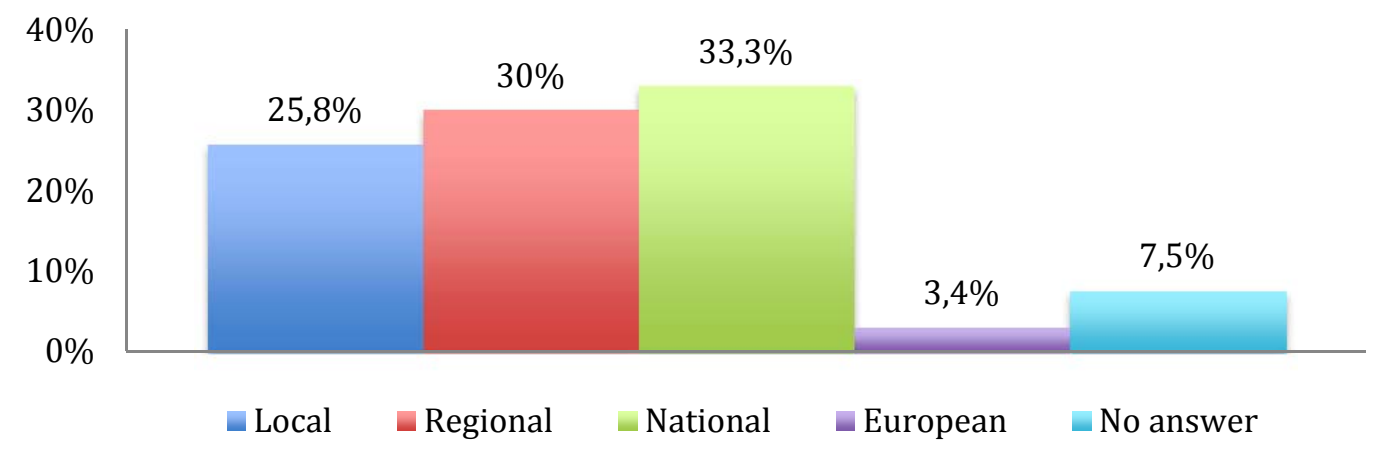

Figure 8: Main responsible institutions for the waste crisis that affect the Campania region.

Burning waste
Landfills
Incinerators
Polluting firms
Marine pollution
Traffic and transport
Illegal building

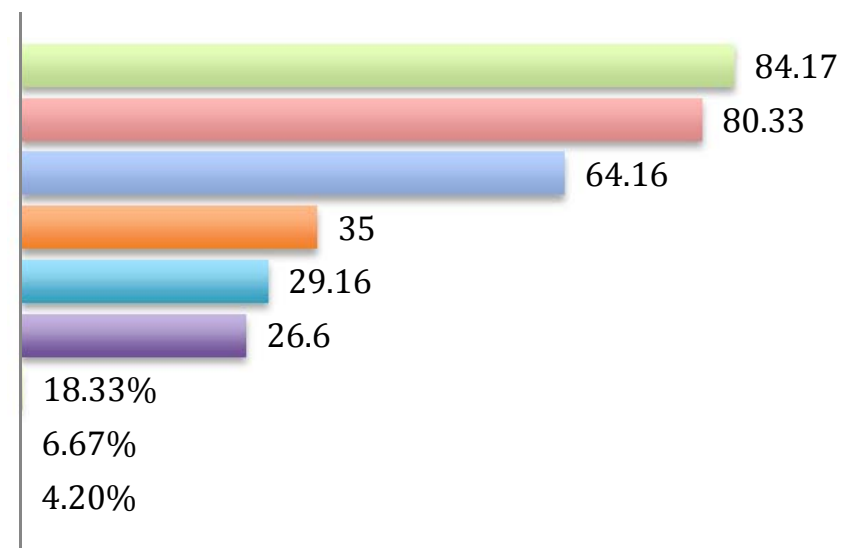

Figure 9: The perceived main critical environmental problem of the place where the respondents live.

A question related to the vicinity of the respondents to a waste treatment plant revealed $91 \%{ }^{32}$ of interviewees said they lived in the vicinity of a waste disposal facility $(35 \%$ close to the incinerator, $28 \%$ close to an illegal landfill, and $23 \%$ close to a legal landfill) (Figure 10).

Finally, and concluding this section of descriptive statistics, it is worth noting the civic and political profiles of the respondents (Figure 11). Many were (or are) members of an environmental association (57\%), and $37 \%$ declared they were or to have been a member of a political party.

\footnotetext{
${ }^{32}$ The sum is not $100 \%$, because a person can live close to more than just one plant (e.g. can live close to an illegal as well as legal landfill).
} 


$$
\begin{aligned}
& \text { Incinerator } \\
& \text { Illegal landfills } \\
& \text { Landfill } \\
& \text { Treatment plant } \\
& \text { Storage plant } \\
& \text { Recycling plant }
\end{aligned}
$$

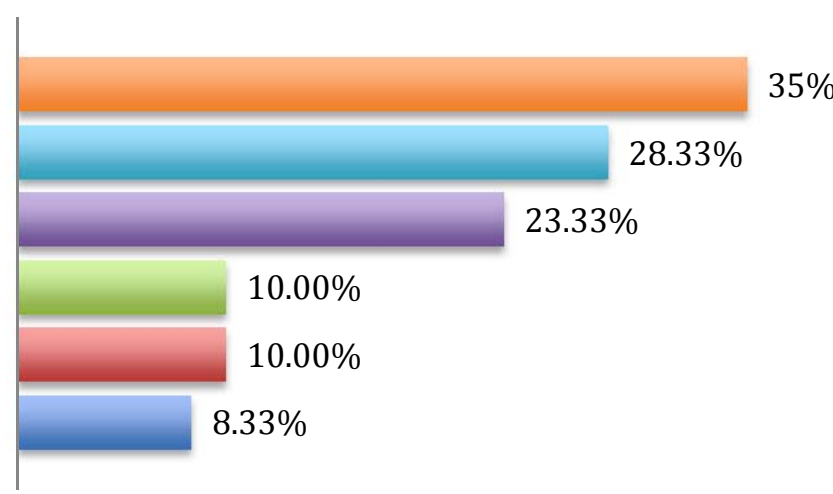

Figure 10: Percentage of respondents who live in the vicinity of a waste disposal and/or treatment plant (legal/illegal).

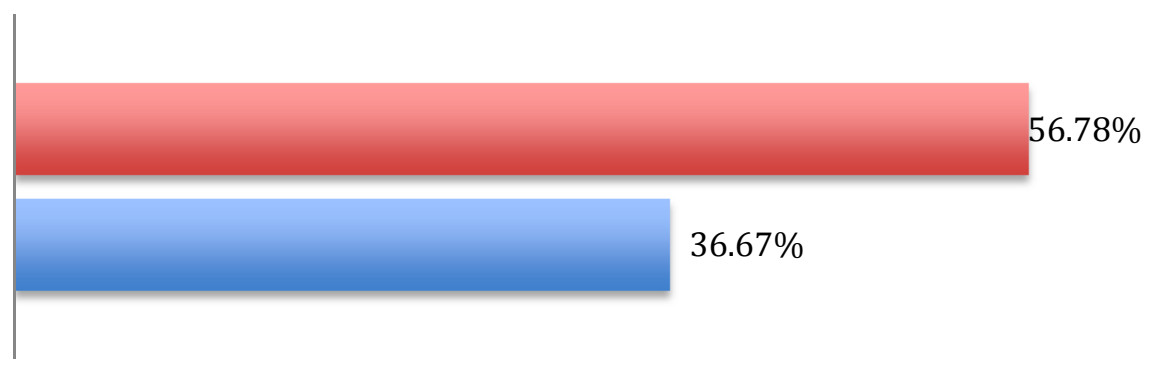

Figure 11: Respondent's membership of political parties and environmental associations.

\section{The determinants of victims' perceptions in the Land of Fires}

In our regression model, the objective is to understand the variations of the dependent variable, i.e. being a victim of environmental crime, by associating it with proportional changes in one or more explanatory variables, i.e. being ill, living in the vicinity of a waste disposal facility, having a certain lifestyle, etc. However, if the variables are multi-collinear, their collective power of explanation is significantly less than the sum of their individual powers to explain the variations of the dependent variable. Thus, in order to check for multicollinearity ${ }^{33}$ (Norliza et al., 2006) we have produced a correlation matrix (Table 4).

\footnotetext{
${ }^{33}$ Where two or more predictor variables in a multiple regression model are highly correlated, meaning that one can be linearly predicted from the others with a substantial degree of accuracy.
} 


\begin{tabular}{|c|c|c|c|c|c|c|}
\hline & victim & $\begin{array}{l}\text { occurrence of } \\
\text { disease }\end{array}$ & $\begin{array}{l}\text { vicinity to } \\
\text { waste } \\
\text { treatment } \\
\text { plants }\end{array}$ & $\begin{array}{c}\text { member of } \\
\text { political party }\end{array}$ & lifestyle & $\begin{array}{l}\text { perceived } \\
\text { quality of the } \\
\text { environment }\end{array}$ \\
\hline victim & 1 & & & & & \\
\hline occurrence of disease & 0.131 & 1 & & & & \\
\hline $\begin{array}{l}\text { vicinity to waste disposal } \\
\text { and/or treatment plants }\end{array}$ & 0.224 & 0.332 & 1 & & & \\
\hline member of political party & 0.086 & 0.169 & -0.067 & 1 & & \\
\hline lifestyle & -0.001 & -0.142 & -0.139 & -0.033 & 1 & \\
\hline $\begin{array}{c}\text { perceived quality of the } \\
\text { environment }\end{array}$ & 0.174 & 0.212 & 0.023 & 0.198 & 0.021 & 1 \\
\hline
\end{tabular}

Table 4: Correlation matrix.

Given the model specifications presented in Section 3, we can observe that there is no strong correlation between any of the independent variables that might pose a specification problem of multicollinearity.

The estimated results derived from the ordered probit model are presented in Table 5. The model has been estimated by the maximum likelihood method and is significant at $1 \%$ level of probability. The estimated coefficients and standard errors tell us which one among the factors analyzed affect respondent's self-perception of being a victim. Particularly, a statistically significant coefficient suggests that the likelihood of perceiving oneself to be a victim will increase/decrease as the response of the explanatory variable increases/decreases.

The results obtained indicate that three variables are statistically significant at $5 \%$ and one at $10 \%$ levels of probability (Table 5). Namely, there is a major likelihood of perceiving oneself to be a victim of an environmental crime if:

a) the person or a family member or a friend has suffered or is suffering serious disease (occurrence of disease in Table 5);

b) there is a perception that the respondent lives in a place characterised by low environment quality (perceived environmental quality in Table 5);

c) the person lives in the vicinity of a legal and/or illegal waste treatment/disposal plant (vicinity to waste disposal/treatment plants in Table 5);

d) he or she is or was a member of a political party and/or of environmental associations (member of political party or environmental association in Table 5).

It is worth nothing that the explanatory variable lifestyle is not statistical significant, so does not explain the variability of being victims of environmental crime. A possible explanation of this could be that the self-perception of being a victim is conditioned by mainly external factors (e.g. legal mismanagement of waste, illegal disposal of waste, waste trafficking, low environmental quality etc., and the consequences of these for health), rather than by personal behavior (e.g. how drinking alcohol or smoking cigarettes can affect health conditions). 


\begin{tabular}{|llllll|}
\hline Variables & Coefficient & Error & $\mathbf{z}$ & $\mathbf{P}>|\mathbf{z}|$ & $\begin{array}{l}\text { Confidence } \\
\text { Interval }\end{array}$ \\
occurrence of disease & 1.039 & .460 & 2.26 & $0.024^{* *}$ & .1373189 \\
vicinity to waste treatment plants & .512 & .286 & 1.79 & $0.074^{*}$ & -.0493496 \\
member of political party & .525 & .277 & 1.90 & $0.058^{*}$ & -.0176693 \\
lifestyle & .113 & .135 & 0.83 & 0.404 & -.1529622 \\
perceived quality of the environment & .532 & .276 & 1.93 & $0.054^{*}$ & -.0092814 \\
/cut ${ }^{34}$ & -.352 & .842 & & & -2.003172 \\
/cut ${ }_{2}$ & .211 & .778 & & & -1.313627 \\
/cut ${ }_{3}$ & 1.547 & .773 & & & .0316408 \\
Log likelihood & -65.188625 & & & & \\
Pseudo R2 & .1007 & & & & \\
LR chi2 & 14.61 & & & & \\
Prob $>$ chi & .0122 & & & & \\
Number of observations & 120 & & & & \\
\hline
\end{tabular}

Significance at $90 \%, 95 \%$ and $99 \%$ respectively with $(*),\left({ }^{*}\right)$ and $(* * *)$.

Table 5: Ordered probit regression.

However, it should be noted that the interpretation of coefficients from an ordered probit model is sometimes not straightforward, since they only provide information on changes to the probability of finding extreme answers (e.g. very high perception of not being a victim and very high perception of being a victim). In particular, a significant positive coefficient (e.g. vicinity to waste treatment plants $=0.512$ ) imply that the distribution of the answers shifts towards the very high perception of being a victim, while a significant negative coefficient would have implied the opposite. As such, the impacts of moderate level of self-perceptions (i.e. high perception of not being a victim, uncertain perception of being a victim and high perception of being a victim) are not directly observed. Therefore, our analysis focuses also on the interpretation of explanatory variables in terms of marginal probability effects. ${ }^{35}$ In a nutshell, the question of interest is: how does the probability of attaining different levels of self-perception of being a victim vary as a result of a unit change in each explanatory variable (e.g. occurrence of diseases, environmental quality, vicinity to waste mismanagement activities, etc.)? In order to determine the impact of such estimators on the probability of each level of self-perception, we derive the associated marginal effects. Table 6 reports the marginal effects that each explanatory variable has on the different scenarios of self-perception of being a victim - that is, the impact that an increase of one unit of the explanatory variables has on the probability of attaining, respectively, a very high perception of not being a victim (Level 1), a high perception of not being a victim (Level 2), an uncertain perception of being a victim (Level 3), a high perception of being a victim (Level 4) and a very high perception of being a victim (Level 5). We built this scale starting from the different responses we received to the question: Do you feel a victim of an environmental crime? The

\footnotetext{
${ }^{34}$ These are the estimated cut-points on the latent variable used to differentiate low victim self-perception from middle, high and very-high victim self-perception when values of the predictor variables are evaluated at zero.

${ }^{35}$ See Greene (2003: 738), for a discussion on calculating marginal effects.
} 
respondents had five different possible answers, according to the Likert scale we used: I strongly disagree, I disagree, I do not disagree nor agree, I agree, and I strongly agree. Thus, a very low level of self-perception stands for I strongly disagree, while a very high level of self-perception of being victims of environmental crime stands for I strongly agree.

\begin{tabular}{ccccccc} 
Variables & \multicolumn{7}{c}{ Marginal effects } \\
Std. Err. & Level 1 & Level 2 & Level 3 & Level 4 & Level 5 \\
$\begin{array}{c}\text { occurrence of disease } \\
\text { vicinity to waste treatment plants }\end{array}$ & .460 & - & -.030 & -.059 & -.269 & .359 \\
$\begin{array}{c}\text { member of political party } \\
\text { perceived quality of the }\end{array}$ & .286 & - & -.005 & -.015 & -.124 & .144 \\
$\quad \begin{array}{c}\text { environment } \\
\text { lifestyle }\end{array}$ & .277 & - & -.005 & -.015 & -.127 & .148 \\
$\quad$
\end{tabular}

Table 6: Marginal effect of independent variables.

As can be observed from Table 6, the marginal effect at level 1 ( $\mathrm{Pr}, \mathrm{Y}=1$ : very high perception of not being a victim) is dropped since nobody declared that they have a very low self-perception of being a victim. The signs on the marginal effects of the significant variables do not remain constant. More specifically, for the second ( $\mathrm{Pr}, \mathrm{Y}=2$ : high perception of not being a victim), for the third ( $\mathrm{Pr}$, $\mathrm{Y}=3$ : uncertain perception of being a victim) and for the four self-perception categories ( $\mathrm{Pr}, \mathrm{Y}=4$ : high perception of being a victim) the statistically significant variables have negative signs, for the fifth self-perception level the sign become positive. In particular, for level 5 ( $\mathrm{Pr}, \mathrm{Y}=5$ very high perception of being a victim, i.e. I strongly agree with the idea of being victim of an environmental crime):

1) a $1 \%$ increase in 'occurrence of disease' is associated with a $36 \%$ increase in the probability of attaining an answer that shows a very high self-perception level;

2) a $1 \%$ increase in the probability of living in the vicinity of waste facilities (as well as of being a member of a political party or an environmental grassroots organization) increases the probability of observing a higher level of self-perception by $15 \%$;

3) a $1 \%$ increase in the probability of living in a surrounding with low level of environmental quality, increases the probability of observing a very high selfperception of being victim by $3 \%$.

This is a crucial result as it shows how strong the very high level of self-perception of being victims is. Particularly, an increase of $1 \%$ in the occurrence of each explanatory variables (occurrence of disease, living in the vicinity of waste facilities, being member of political parties and/or environmental association, living in a place with a low level of environmental quality) increase much more than proportionally $(36 \%, 15 \%, 15 \%$ and $3 \%$ respectively) the probability of obtaining an response that strongly agrees with the idea of being a victim of an environmental crime. This finding shows that the more those four variables occur, the more the answer of the respondents will polarize towards the higher level of self-perception of being a victim, and less and less the other victims' level of self-perception will appear. Or, said another way, this polarisation of perspectives suggests that a $1 \%$ increase in any of the occurrences (i.e. independent variables) considered in our model would determine an increase in victims' self-perception level only for the fifth (i.e. very high perception of being a victim) level. This reveals that in the respondents' opinion, the condition of being a victim is deeply perceived, and any other level of perception is residual and marginal, i.e. you are a victim or you are not! 


\section{Conclusion}

Environmental crimes affect different groups in society. It is compelling to try and understand how to stop, or at least to slow down, those responsible for this formidable thriving business. A major legacy of crimes against the environment are their health consequences for human bodies. The slow violence of contamination shows up in new patterns of disease, and makes people aware of the possible dangerous consequences of activities normally invisible to the routine gaze.

The political ecology of health approach in this article tries to reveal the complexities of the waste crisis in and around Naples. This is one of the most serious failures of waste management in Europe. Several factors have led to the present crisis; the political economic incentives for illegal waste disposals, the territorial power of the camorra, the bribery and corruption that has characterised some cohorts of state officials, the inability of national politicians to face the emergent business of waste trafficking, and the incompetence of the regional political government to initiate and manage a participatory urban waste plan. These have created the synergetic conditions for the consolidation of a business venture that sits between legal enterprises, camorra families and government officers. This intricate web of interests has been able to secure a cheap dump for:

(1) a myriad of small illegal business in the Campania region;

(2) hazardous waste from northern Italy;

(3) other toxic waste coming from other European countries.

On the political side, the implementation of 'state of emergency' measures in 1994 silenced citizens' opposition to the disastrous waste activities in the region. However, the continuous increase of cancer morbidity and mortality has reactivated civic unrest to stop the 'biocide', to use the words that activists employ to name the phenomenon. A contrasting official narrative, supported by the studies commissioned by public authorities, relates the rise in diseases in the region mainly to the poor lifestyle of Campania citizens. The disease controversy continues to fuel the perception of those affected that they are not being protected by public institutions against environmental crime; thus health has become the core issue in this environmental conflict. Indeed, the contraction of serious illnesses, and living in a sick environment, are very important variables that explain the selfperception of being a victim in the Land of Fires. Uncertainty about the toxic legacy in Campania fuels the waste struggle, and it can be solved only if political bodies support participatory epidemiological studies as well as strong legal protection for victims of environmental crime.

\section{References}

Abbott A. 2014. A toxic legacy. Nature 508: 431.

ARPAC. 2005. Piano regionale di bonifica dei siti inquinati della regione Campania. www.arpacampania.it

Auyero J. and D. Swistun. 2008. The social production of toxic uncertainty. American Sociological Review 73(3): 357-379.

Barbieri, R. and D. Piglionica. 2007. Commissione parlamentare d'inchiesta sul ciclo dei rifiuti e sulle attività illecite ad esso connesse, doc. XXIII n. 2, Parliamentary report, available on line at http://www.camera.it/_dati/leg15/lavori/documentiparlamentari/indiceetesti/023/002_RS/pdfel. $\underline{\mathrm{htm}}$

Barclay E. and R. Bartel. 2015. Defining environmental crime: the perspective of farmers. Journal of Rural Studies 39 (5): 188-198.

Bricknell, S. 2010. Environmental crime in Australia. Research and Public Policy Series 109. Australian Institute of Criminology, Canberra.

Cameron, A.C. and P.K. Trivedi. 2005. Binary outcome models. In Cameron A.C. and P.K. Trivedi (eds.). Microeconometrics: methods and applications. Cambridge: Cambridge University Press. Pp. 465-475.

Capocaccia R., P. Comba, S. Conti, R. De Angelis, P. Della Porta, F. Falleni, L. Fazzo, A. Federici, G. Ferrante, S. Francisci, L. La Sala, V. Manno, M. Masocco, V. Minardi, G. Minelli, L. 
Musmeci, R. Pizzuti, S. Rossi, G. Ruocco, S. Salmaso and G. Ziemacki. 2012. Situazione epidemiologica della regione Campania ed in particolare delle province di Caserta e Napoli (città esclusa), con riferimento all'incidenza della mortalità per malattie oncologiche. Final report, del Gruppo di Lavoro ex D.M. 24.07.2012

Comba, P., Ascoli, V., Belli, S., M. Benedetti, L. Gatti, P. Ricci, and A. Tieghi. 2003. Risk of soft tissue sarcomas and residence in the neighbourhood of an incinerator of industrial wastes. Occupational and Environmental Medicine 60: 680-683.

Costa, A.M. 2008. Rule of law: a "missing" Millennium Development Goal Speech at 17th session of the United Nations Commission on Crime Prevention and Criminal Justice, Vienna.

Di Chio F. and D. Martini. 2009. Parla il pentito Schiavone. "Ecco la vera. Gomorra." http://www.iltempo.it/cronache/2012/12/12/parla-il-pentito-schiavone-br-ecco-la-veragomorra-1.206464

D'Alisa G., M. Armiero and P.S. De Rosa. 2014. Political ecology: rethinking Campania's toxic-waste scandal (letter). Nature 509: 427.

D'Alisa G., P.M. Falcone, A. Germani, C. Imbriani, P.G. Morone and F. Reganati. 2015. Victims in the "Land of Fires": a case study on the consequences of burnt and buried waste in Campania, Italy. EFFACE project - European Union Action to fight Environmental crime. Available at: http://efface.eu/wp4-environmental-crime-case-studies

de Falco G. 2014. Traffico illecito dei rifiuti: un approaccio giudiziario. Gazzetta Ambiente 4: 71 - 75.

De Rosa, P.S. 2014. The remaking of toxic territories: grassroots strategies for the re-appropriation of knowledge and space in the socio-environmental conflicts of Campania, Italy. Presented at the Political Studies Association Conference; Voice and Space: new possibilities for democracy in Southern Europe? Manchester, April 14-16.

Europol 2013. Threat assessment 2013: environmental crime in the EU. Europol Public Information.

ECOSOC 1994. The role of criminal law in the protection of the environment. Resolution 1994/15; Economic and Social Council, UN. Available at: http://www.un.org/documents/ecosoc/res/1994/eres1994-15.htm

EFFACE 2014. Draft analytical framework and cluster guidelines. www.efface.eu

Fazzo L., S. Belli, F. Mitis, M. Santero, L. Martina, R. Pizzuti, P. Comba and M. Martuzzi. 2008. Analisi dei clusters di mortalità in un'area con una diffusa presenza di siti di smaltimento dei rifiuti urbani e pericolosi in Campania. Istituto Superiore di sanità. Available online at: http://www.iss.it/binary/epam/cont/FAZZO Rifiuti.1159881860. pdf

Fontana. E., A. Pergolizzi, P. Ruggiero, F. Dodaro, C. Groccia, S. Ciafani and R. Del Giudice. 2008. Rifiuti Spa. Legambiente http://www.borsarifiuti.com/materiali.phpsc? $\mathrm{i}=\mathrm{d}$

Goldberg, M.S., N. al-Homsi, L. Goule and H. Riberdy. 1995. Incidence of cancer among persons living near a municipal solid waste landfill site in Montreal, Quebec. Archives of Environmental Health 50: 416-424.

Goldberg, M.S., J. Siemiatyck, R. DeWar, M. Désy and H. Riberdy. 1999. Risks of developing cancer relative to living near a municipal solid waste landfill in Montreal, Quebec, Canada. Archives of Environmental Health 54: 291-296.

Goodey, J. 2005. Victims and victimology: research, policy and practice. London: Pearson Education.

Gregson R. and L. Court. 2010. Building healthy communities: a community empowerment approach. London: Community Development Foundation.

Hall, M. 2013. Environmental victims: challenges for criminology and victimology in the 21th century. Journal of Criminal Justice and Security 4: 371-391.

Hall, M. 2014. Environmental harm and environmental victims: scoping out a "green victimology." International Review of Victimology 201: 129-143.

Halsey, M. 2004. Against green criminology. British Journal of Criminology 44(6): 833-853.

Harper J. 2004. Breathless in Houston: a political ecology of health approach to understanding environmental health concerns. Medical Anthropology: Cross-Cultural Studies in Health and Illness 23(4): 225-236. 
Houston D. and K. Ruming. 2014. Suburban toxicity: a political ecology of asbestos in Australian cities. Geographical Research 52(4): 400-410.

Iacuelli A. 2007. Le vie infinite dei rifiuti. Il sistema campano. Italy: Edizioni Rinascita.

Iengo, I. and M. Armiero 2017. The politicization of ill bodies in Campania, Italy. Journal of Political Ecology 24: 44-58.

Interpol 2006. Assessing the links between organized crime and pollution crimes. Interpol Pollution Crimes Working Available at: https://www.interpol.int/Public/EnvironmentalCrime/Pollution/WorkingGroup.asp

King B. 2010. Political ecologies of health. Progress in Human Geography 341: 38-55.

Kearns R. and W. Gesler. 1998. Putting health into place: landscape, identity and well-being. New York: Syracuse University Press.

Korsell, L.E. 2001. Big stick, little stick: strategies for combating environmental crime. Journal of Scandinavian Studies in Criminology and Crime 2(2): 127-148.

Jackson P. and A.H. Neely. 2015. Triangulating health: toward a practice of a political ecology of health. Progress in Human Geography 39(1): 47-64.

Jarrell M. and J. Ozymy. 2014a. Communities as victims of environmental crime: lessons from the field. In Spapens T., R. White and M. Kluin (eds.) Environmental crime and its victims. Farnham: Ashgate.

Jarrell M. and J. Ozymy. 2014b. Few and far between: understanding the role of the victim in the federal environmental crime prosecutions in the United States. Crime, Law and Social Change 61: 563-584.

Lynch M.J. and P.B. Stretsky. 2003. The meaning of green: contrasting criminological perspectives. Theoretical Criminology 7(2): 217- 238.

La Rocca S. 2014. Traffico illecito dei rifiuti: normative e politiche poste a confronto. Gazzetta Ambiente 4: 41-59.

Legambiente. 2003, 2013 Rapporto Ecomafia.

Magiameli, G. 2013. From mourning to environmentalism: a Sicilian controversy about children's deaths, political apathy and leukaemia. Journal of Political Ecology 20: 318-328.

Martín A.M., B. Hernández, S. Hess, C. Ruiz and I. Alonso. 2013. The relationship between moral judgments and causal explanations of everyday environmental crimes. Social Justice Research 26(3): 320-342.

Martinez-Alier, J., I. Anguelovski, P. Bond, D. Del Bene, F. Demaria, J.F. Gerber, L. Greyl, W. Haas, H. Healy, V. Marín-Burgos, G. Ojo, M.F. Porto, L. Rijnhout, B. Rodríguez-Labajos, J. Spangenberg, L. Temper, R. Warlenius and I. Yánez. 2014. Between activism and science: grassroots concepts for sustainability coined by environmental justice organizations. Journal of Political Ecology 21: 19-60.

Martuzzi M., F. Bianchi, P. Comba, L. Fazzo, F. Minichilli and F. Mitis (eds.). 2005. Trattamento dei rifiuti in Campania: impatto sulla salute umana. Studio pilota, available online at: www.protezionecivile.it

Mayer J.D. 1996. The political ecology of disease as one new focus for medical geography. Progress in Human Geography 20(4): 441- 456.

Maselli V., G. Polese, D. Rippa, R. Ligrone, R.K. Rastogi and D. Fulgione. 2010. Frogs, sentinels of DNA damage induced by pollution in Naples at the neighbouring provinces. Ecotoxicology and Environmental Safety 73(7):1525-1529. Researchgate

Mitchell, J.K. 1996. The long road to recovery: community responses to industrial disasters. In Mitchell J.K. (ed.). The long road to recovery: community responses to industrial disaster. Tokyo: United Nations University Press.

Musella, A. 2008. Mi rifiuto! Le lotte in difesa della salute e dell'ambiente in Campania. Dogliani: Sensibili alle foglie.

Nixon, R. 2011. Slow violence and the environmentalism of the poor. Cambridge, MA: Harvard University Press.

Norlizla A., H.A. Maiza and A. Robiah. 2006. A comparative study on some methods for handling 
multicollinearity problems. Matematika 22(2): 109-119.

O'Hear M. 2004. Sentencing the green-collar offender: punishment, culpability and environmental crime. Journal of Criminal Law and Criminology 95(1): 133-276.

Parodi, S., R. Baldi, C. Benco, M. Franchini, E. Garrone, M. Vercelli, F. Pensa, R. Puntoni and V. Fontana. 2004. Lung cancer mortality in a district of La Spezia (Italy) exposed to air pollution from industrial plants. Tumori 90: 181-185. Researchgate

Parizeau K. 2015. Urban political ecologies of informal recyclers' health in Buenos Aires, Argentina. Health and Place 33: 67-74. Researchgate

Pellow, D. 2007. Resisting global toxics: transnational movements for environmental justice. Cambridge MA: MIT Press.

Persi, G. 2014. Contrasto alla gestione illecita dei rifiuti. Gazzetta Ambiente 4: 66-70.

Pezzullo, P. and R. Sandler. 2007. Revisiting the environmental justice challenge to environmentalism. In Sandler, R. and Pezzullo P. (eds.) Environmental justice and environmentalism: the social justice challenge to the environmental movement. Cambridge, MA: MIT Press.

Poncelet, C. 2012. Access to justice in environmental matters: does the European Union comply with its obligations? Journal of Environmental Law 24(2): 287-309.

Rajaguru, P., S. Suba, M. Palanivel and K. Kalaiselvi. 2003. Genotoxicity of a polluted river system measured using the alkaline comet assay on fish and earthworm tissues. Environmental and Molecular Mutagenesis 41: 85-91.

Saviano, R. 2006. Gomorra. Mondadori ed. English translation: 2007: Gomorrah: a personal journey into the violent international empire of Naples' organized crime system. New York: Picador.

Scalia, M. 2000. Documento sui traffici illeciti e le ecomafie, Commissione Parlamentare d'Inchiesta sul ciclo dei Rifiuti e sulle Attvità ad esso connesse.

Seager, J. 1993. Earth follies: coming to feminist terms with the global environmental crisis. New York: Routledge.

Senior, K. and A. Mazza. 2004. Italian "Triangle of Death" linked to waste crisis. The Lancet Oncology 5: 525-527.

Skinnider E. 2011. Victims of environmental crime - mapping the issues. Research Report. Vancouver: International Centre for Criminal Law Reform and Criminal Justice Policy. Researchgate

Skinnider E. 2013. Effect, issues and challenges for victims of crimes that have a significant impact on the environment. Research Report. Vancouver: International Centre for Criminal Law Reform and Criminal Justice Policy.

Smarazzo, D. 1999. Area Metropolitana di Napoli. Documenti e studi per una definizione dell'area Metropolitana di Napoli. Maggiori Editori.

South N. 1998. A green field for criminology? A proposal for a perspective. Theoretical Criminology 2(2): 211-234.

Spapens T., R. White and M. Kluin (eds.). 2014. Environmental crime and its victims: Perspectives within green criminology. Farnham: Ashgate.

Spapens T. 2015. Invisible victims: the problem of investigating environmental crime. Presented at Environmental crime and its victims, Tilburg. www.environmentalcrimeseminar.com.

Spencer, D. and A. Fitzgerald. 2013. Three ecologies, transversality and victimization: the case of the British Petroleum oil spill. Crime, Law and Social Change 59(3): 209-223.

Stahl Jr., R.G. 1991. The genetic toxicology of organic compounds in natural waters and wastewaters. Ecotoxicology and Environmental Safety 22; 94-125.

Tombs S. and D. Whyte. 2010. Regulatory surrender: death, injury and the non-enforcement of law. London: Institute of Employment Rights.

White, R. 2004. Environmental crime in global context: exploring the theoretical and empirical complexities. Current Issues in Criminal Justice 16: 271-285.

White, R. 2008. Crimes against nature: environmental criminology and ecological justice. 
Cullompton: Willan Publishing.

White, R 2011. Transnational environmental crime: towards an eco-global criminology. London: Routledge.

Wiernik, C. 2006. An integrated criminological theoretical framework for examining environmental crime. Paper presented to the annual meeting of the American Sociological Association, Montreal Canada.

http://www.allacademic.com/meta/p_mla apa_research_citation/1/0/4/2/2/p104225 index.html

Wiernik, C. 2006. An integrated criminological theoretical framework for examining environmental crime. Paper presented to the annual meeting of the American Sociological Association, Montreal Canada, Available online

http://www.allacademic. com $/ \mathrm{meta} / \mathrm{p}$ mla apa research_citation $/ 1 / 0 / 4 / 2 / 2 / \mathrm{p} 104225$ index.html.

Williams C. 1996. An environmental victimology. Social Justice 23(4): 16-40.

World Health Organization, Istituto Superiore della Sanità, Consiglio Nazionale delle Ricerche e Regione Campania (Assessorato alla Sanità. 2005. Trattamento dei rifiuti in Campania: impatto sulla salute umana. Studio pilota. Available online at: www.protezionecivile.it 